
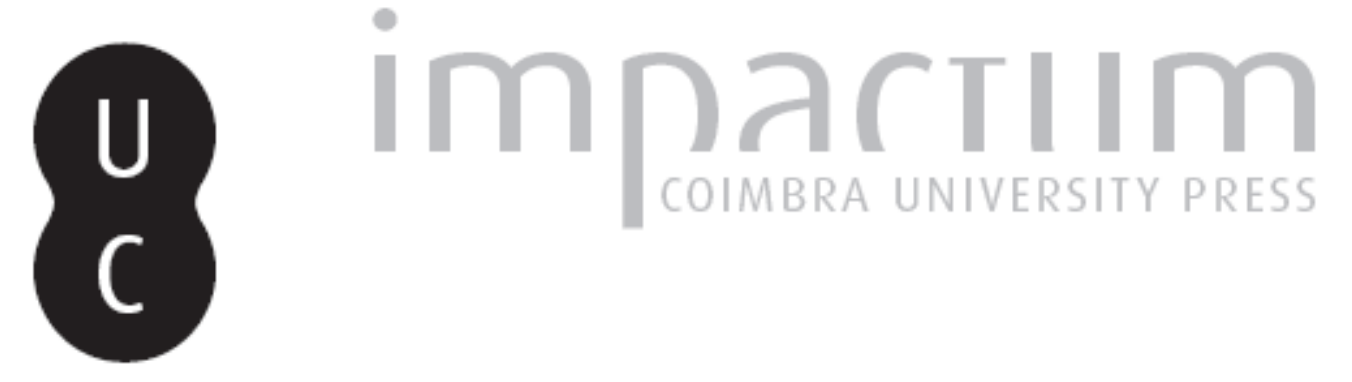

\title{
Daniel Rodriga: um dos grandes protagonistas das Nações Portuguesas do mediterrâneo
}

Autor(es): $\quad$ Leoni, Aron di Leone; Andrade, António Manuel Lopes

Publicado por: Imprensa da Universidade de Coimbra

URL persistente:

URI:http://hdl.handle.net/10316.2/45004

DOI:

DOI:https://doi.org/10.14195/0870-4147_38_9

Accessed : $\quad$ 26-Apr-2023 11:27:12

A navegação consulta e descarregamento dos títulos inseridos nas Bibliotecas Digitais UC Digitalis, UC Pombalina e UC Impactum, pressupõem a aceitação plena e sem reservas dos Termos e Condições de Uso destas Bibliotecas Digitais, disponíveis em https://digitalis.uc.pt/pt-pt/termos.

Conforme exposto nos referidos Termos e Condições de Uso, o descarregamento de títulos de acesso restrito requer uma licença válida de autorização devendo o utilizador aceder ao(s) documento(s) a partir de um endereço de IP da instituição detentora da supramencionada licença.

Ao utilizador é apenas permitido o descarregamento para uso pessoal, pelo que o emprego do(s) título(s) descarregado(s) para outro fim, designadamente comercial, carece de autorização do respetivo autor ou editor da obra.

Na medida em que todas as obras da UC Digitalis se encontram protegidas pelo Código do Direito de Autor e Direitos Conexos e demais legislação aplicável, toda a cópia, parcial ou total, deste documento, nos casos em que é legalmente admitida, deverá conter ou fazer-se acompanhar por este aviso.

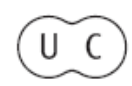



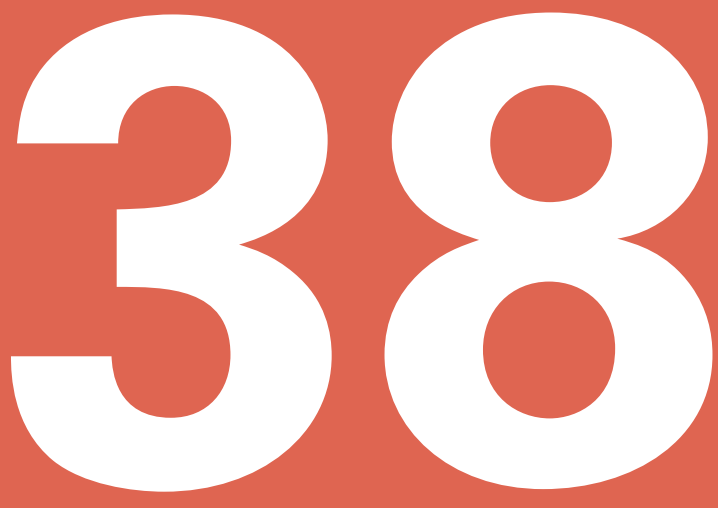

\section{Revista Portuguesa de História}

Faculdade de Letras da Universidade de Coimbra Instituto de História Económica e Social

Coimbra 08 
Revista Portuguesa de História

t. XXXVIII (2006)

pp. $219-263$

\section{Daniel Rodriga, um dos grandes protagonistas das Nações Portuguesas do Mediterrâneo*}

Aron di LeONE LeONI

António Manuel Lopes Andrade

Departamento de Línguas e Culturas - Universidade de Aveiro

\section{Um Judeu Português na Veneza de Quinhentos}

Neste estudo, apresentamos alguns documentos inéditos sobre Daniel Rodriga ou Rodrigues ${ }^{1}$, o primeiro ${ }^{2}$ cônsul $^{3}$ das Nações Hebraicas Levantina

*Agradecemos o inestimável auxílio prestado na realização deste trabalho pelos Prof. Doutores Clarinda de Azevedo Maia e Saul António Gomes, da Faculdade de Letras da Universidade de Coimbra. Expressamos igualmente a nossa gratidão à Memorial Foundation for Jewish Culture de Nova Iorque pelo apoio concedido ao desenvolvimento da investigação.

ABREVIATURAS

AHD = Arquivo Histórico de Dubrovnik (Državni Arhiv u Dubrovniku);

ASAn $\quad=$ Archivio di Stato di Ancona;

$\mathrm{ASFe} \quad=$ Archivio di Stato di Ferrara;

ASMo = Archivio di Stato di Modena (Cancelleria Ducale);

ASVe, CSM = Archivio di Stato di Venezia, Cinque Savi alla Mercanzia;

IAN/TT = Instituto dos Arquivos Nacionais/Torre do Tombo, Lisboa.

1 Na documentação e na literatura existentes sobre este judeu brigantino, incluindo o próprio testamento que ora se publica, a forma do apelido utilizada foi, com poucas excepções, Rodriga. Por essa razão, foi esta a adoptada ao longo do trabalho, sempre que Daniel Rodriga ou outros membros da sua família são nomeados. O apelido Rodriga (tal como Rodrigo) foi, aliás, usado pelos judeus portugueses antes mesmo da conversão geral, como comprovam diversos documentos 
e Ponentina ${ }^{3}$ de Veneza, de entre os quais destacamos, pela sua importância, o próprio testamento do judeu brigantino, firmado em Veneza, no ano de 1603, que foi redigido em língua portuguesa.

Daniel Rodriga ocupa um lugar de destaque na história da república de Veneza, na medida em que projectou e executou a Scala (ou seja, o porto franco) de Split (conhecida vulgarmente pela designação italiana de Spalato) e um novo caminho marítimo transadriático que, ligando Veneza ao novo empório, permitiu redireccionar para a Sereníssima uma parte conspícua das trocas comerciais entre a Europa e o Império Turco. No plano gizado pelo judeu português, o desenvolvimento da praça de Split devia estar, e esteve efectivamente, correlacionado com o projecto de acolher oficialmente no Ghetto de Veneza uma colónia de mercadores portugueses com liberdade para professar a religião mosaica e dedicar-se ao comércio internacional.

Antes de falarmos de Daniel Rodriga, julgamos indispensável ilustrar, ainda que de forma breve, o papel económico desempenhado por um primeiro núcleo da Nação Hebraica Portuguesa que se veio a constituir no Ghetto Vecchio de Veneza, a partir dos anos 50 do século XVI. De facto, a dimensão e a própria

à guarda do IAN/TT, apresentados por Maria José Pimenta Ferro TAVAREs, Os Judeus em Portugal no século XV, vol. II, Lisboa 1984. Assim, a título de exemplo, encontra-se registo de um Moisés Rodriga (o mesmo nome, por sinal, do pai do nosso Daniel Rodriga), em Trancoso, em 1574 (p. 378); de um outro (ou, eventualmente, o mesmo) Moisés Rodriga, em Trancoso, em 1491, com as funções de escrivão da câmara, sisão e genesim (p. 378); de Isaac e José Rodriga, em Viseu, em 1576 (p. 389).

1 Daniel Rodriga foi certamente a primeira figura que obteve, oficialmente, o título de Cônsul da Nação Hebraica [Ponentina e Levantina], embora não tenha sido o primeiro que exerceu esta actividade. Na verdade, foi precedido por Hayim Saruc que, apesar de não ter recebido o título de Cônsul, desempenhou as mesmas funções, apresentando-se simplesmente na qualidade de agente dos mercadores hebreus. Veja-se B. Pullan, «A Ship with two Rudders, Righetto Marrano and the Inquisition in Venice»: The Historical Journal XX (1997), pp. 25-58: 37. Este investigador definiu Saruc «Some time Consul of the Levantine Jews in Venice». A propósito de Saruc, cf. B. Arbel, Trading Nations, Jews and Venetian in the Early Modern Mediterranean, Leiden 1995, pp. 95-168.

2 Em 1573, o Doge Mocenigo concedeu a Daniel Rodriga o título de Cônsul da Nação Hebraica de Veneza.ASVe, CSM, busta 63, fascículo intitulado postumamente: "Ebrei Ponentini". Cf. A. di Leone Leoni, «Una Teshuvà del Ma"harashdam di Salonicco su una vertenza tra due Consoli Ebrei e il ruolo economico dei mercanti ebrei nella Venezia del Cinquecento»: Zakhor, Rivista di Storia degli Ebrei d'Italia 7 (2004), pp. 143-192: 150-151, 181 (documento n. ${ }^{\text { 8). }}$

3 Ponentina = Portuguesa e Espanhola: para a distinção entre Levantinos e Ponentinos, veja-se o estudo fundamental de R. BonfIL, «The History of Spanish and Portuguese Jews in Italy»: Haim BeInART (ed.), Moreshet Sepharad: the Sephardi Legacy, II, Jerusalem 1992, pp. 217-339. 
presença desta Nação há muito que têm sido negligenciadas pelos historiadores de Veneza e, até, pelos investigadores especializados na história judaica.

\section{§ 1. Veneza, os Judeus e o Comércio com o Levante}

Durante muitos séculos, o comércio marítimo (e, em seguida, também terrestre) com o Levante, e sobretudo com Istambul, tinha estado na origem da prosperidade económica da Sereníssima. No seio da sociedade veneziana, esta actividade estava desde há muito reservada a uma oligarquia da qual faziam parte apenas os nobres e um círculo restrito de cidadãos privilegiados. Os estrangeiros e os judeus, em particular, foram obstinadamente excluídos deste negócio. No entanto, no início do século XVI, Veneza foi obrigada a permitir que os súbditos do Grande Turco se dedicassem ao comércio internacional, uma medida recíproca face ao Império Otomano, que sempre havia oferecido aos mercadores venezianos uma generosa hospitalidade. Assim, desde o início do século XVI, Veneza aceitou a presença de mercadores hebreus orientais ou "levantini". Em 1541, foi-lhes atribuída como residência uma zona designada como Ghetto Vecchio, adjacente ao Ghetto Nuovo, onde estava confinada a comunidade dos hebreus tudescos que compreendia também uma componente de origem italiana. Os habitantes destes dois pequenos quarteirões hebraicos estavam sujeitos a um distinto ordenamento jurídico e económico ${ }^{4}$.

Os judeus alemães (e com eles os italianos) podiam praticar empréstimos sob penhor e ter negócios de «strazzaria», onde, supostamente, apenas podiam vender vestuário já usado, se bem que, na realidade, comerciassem também fazendas novas, tecidos valiosos e uma grande variedade de mercadorias entre as quais, por vezes, figuravam, até, jóias e pedras preciosas ${ }^{5}$.

Osjudeus levantinosnão podiam dedicar-seaocomérciolocal,nem,muitomenos, possuir lojas abertas ao público, no Ghetto ${ }^{6}$. A sua actividade estava originaria-

4 D. JACOBY, «Les Juifs à Venise du XIV e au milieu du XVI ${ }^{\mathrm{e}}$ siècle»: H. G. BECK, Venezia, Centro di Mediazione tra Oriente e Occidente, Firenze 1977, pp. 163-185; B. RAVID, «The Venetian Government and the Jews»: R. C. DAvis - B. RAvid (eds.), The Jews of Early Modern Venice, Baltimore and London 2001, pp. 3-30.

5 Sobre o desenvolvimento desta actividade no século XVI, cf. B. Pullan, La Politica Sociale della Repubblica di Venezia, Roma 1982, pp. 605-606 (tradução italiana de Rich and Poor in Renaissance Venice: the Social Institutions of a Catholic State, to 1620, Oxford 1971); A. di LEONE LEONI, «Alcuni esempi di quotidiana imprenditorialità tra Ferrara, Ancona e Venezia nel XVI secolo»: Zakhor, Rivista di Storia degli Ebrei d'Italia 4 (2000), pp. 57-114: 62-67, 92-93.

6 Investigações recentes vieram demonstrar que os mercadores judeus, na segunda metade de Quinhentos, obtiveram autorização de manter armazéns na zona de Rialto. Em relação ao saque dos armazéns de Rialto, onde estavam depositadas as mercadorias dos judeus levantinos, durante 
mente limitada à importação de produtos balcânicos, especialmente couros, peles, lã em rama, cera e tecidos, sobretudo os famosos zambelotti e mocaiatti ${ }^{7}$. Os mercadores hebreus de Veneza exportavam os produtos da indústria local: tecidos de lã e de seda, vidros, cristais $^{8}$ e alimentos muito valorizados como, por exemplo, o célebre queijo parmesão9.

Por volta de meados do século XVI, estabeleceram-se também no Ghetto Vecchio numerosos portugueses, ex-conversos, que se declararam publicamente como judeus (embora nem sempre como levantinos) e deram um contributo significativo ao comércio com o Levante. Graças à sua intensa actividade, o empório de Veneza tornou-se um dos principais pontos de passagem e de comércio dos tecidos ingleses e flamengos, bastante procurados no Levante.

a Guerra de Chipre, vide ASVe, Consiglio dei X, Secreti, Reg. 11, fls. 24r-24v. Cf. B. Arbel, «Venezia, gli Ebrei e l'attività di Salomone Ashkenazi nella Guerra di Cipro»: G. Cozzi (ed.), Gli Ebrei e Venezia: secoli XIV-XVIII, Milano 1987, pp. 163-190: 188, nota 78; veja-se também: ASVe, Inquisitorato agli Ebrei, busta 19, fls. 371r-374v: petição apresentada, em 1590, pelos Judeus Levantinos aos Cinque Savi alla Mercanzia em favor de Hayim Saruc, publicada por A. di Leone Leoni, «Una Teshuvà del Ma”harashdam di Salonicco...», op. cit., pp. 189-191, doc. 21.

Por outra parte, David Membrech declara no seu testamento (ASVe, Notarile Testamenti, notaio G.A.Catti, B. 348, 20.4.1589) que algumas importantes remessas de peveri, provenientes de portos da Dalmácia, estavam depositadas em duas «volte» (armazéns), em Rialto. A partir de outras fontes, sabe-se ainda que, em certas ocasiões, os judeus italianos beneficiaram de idênticas autorizações: ASVe, not. G. B. Monti, 22.8.1564.

7 Os zambelotti (ditos também ciambelotti o camelotti) eram panos entretecidos com pêlo de camelo e de cabra, que eram bastante procuradas em razão do seu preço substancialmente inferior ao dos tecidos "ultrafini". Os mocaiatti, por outro lado, eram fazendas de lã mais finas e valiosas que os zambelotti.

8 Veja-se, a título de exemplo: Archivio di Stato di Venezia, Notarile Antico, not. Giovan Battista Monti, registo 8257, 18.8.1569, O judeu português Cayn de Jacob Cohen adquire paternostri de vidro (era esta a designação vulgar pela qual eram conhecidas, no dialecto veneziano, as contas de vidro dos rosários ou mesmo, por arrastamento, os próprios rosários), a entregar ao português Samuel Carabon, pela soma de 568 ducados e 68 grossos. Caim Cohen, alias Simão Anriques, era um dos filhos do mercador português Henrique Pires, que se distinguiu como um dos membros mais proeminentes da Nação Portuguesa de Antuérpia e de Ferrara. Como se comprovou recentemente, Henrique Pires, alias Yacob Cohen, de quem o célebre humanista e poeta Diogo Pires era também filho, acabou os seus dias entre as mais de duas dezenas de judeus portugueses que foram martirizados nos autos-de-fé de Ancona, em 1556. Para uma análise pormenorizada da constituição e das actividades da família eborense Pires-Cohen, veja-se o estudo de A. M. L. Andrade, O Cato Minor de Diogo Pires e a Poesia Didáctica do séc. XVI, Aveiro 2005 (dissertação de doutoramento), cuja primeira parte (pp. 1-134) traça um esboço biográfico de Diogo Pires e da família Pires-Cohen.

9 Cf. B. Arbel, «Jews in International Trade»: R. C. DAvis - B. Ravid (eds.), The Jews of Early Modern Venice, op. cit., pp. 73-96: 84-85; A. di LEONE LEONI, «Alcuni esempi di quotidiana imprenditorialità...», op. cit., pp. 57-114: 92-103 e 113-114. 
Os portugueses de Veneza especializaram-se também no comércio de alúmen, um produto utilizado tanto na indústria têxtil como na vidreira.

O extraordinário florescimento destas actividades comerciais tornou-se possível devido a um fenómeno que até hoje obteve escassa atenção da parte dos historiadores: a formação ao longo de toda a costa adriática e mediterrânica do Império Otomano de uma fina rede de colónias comerciais hebraicas, formadas maioritariamente por cristãos-novos portugueses que se dedicaram às actividades industriais, mercantis e artesanais. Em redor de meados de Quinhentos, Salonica tinha uma população hebraica com mais de vinte mil habitantes, agrupados em diversas comunidades, segundo a sua origem étnica e os seus ritos religiosos ${ }^{10}$. Além de estar dotada de um importante porto sobre o Mar Egeu, esta cidade situava-se no eixo de importantes vias terrestres que a ligavam a Istambul e à Ásia Menor, ao interior balcânico e aos centros produtivos da Grécia continental e da Moreia (Peloponeso). Salonica tornou-se rapidamente um centro manufactureiro de primeira grandeza, e a sua população, em maioria hebraica, dedicou-se não só à tecelagem da lã e da seda, mas também ao curtume e tratamento de peles e ao comércio com outras cidades do Império Otomano e com as praças italianas situadas nas margens do Adriático.

A indústria têxtil desta cidade foi criada por empreendedores hebreus ${ }^{11}$ que empregaram milhares de trabalhadores, tanto gregos como judeus, em todas as fases do processo industrial ${ }^{12}$. Os judeus mostraram-se bastante activos em variadíssimas actividades e puderam participar livremente em todas as corporações artesanais, algumas das quais eram compostas, exclusiva ou maioritariamente, por eles próprios ${ }^{13}$. Os mercadores e artesãos hebreus foram favorecidos pela política económica do Império Turco que facilitava a criação e o desenvolvimento de novos centros manufactureiros e comerciais e via com

${ }^{10}$ Os judeus de origem espanhola e portuguesa constituíam a esmagadora maioria da população hebraica. A este propósito, cf. J. Nehama, «The Jews of Salonika in the Ottoman Period»: R. D. Barnett - W. M. Schwab (eds.), The Sephardi Heritage: Essays on the History and the Cultural Contribution of the Jews of Spain and Portugal, vol. II, Grendon 1971-1989, pp. 203-242; Joseph HACKER, «The Sephardim in the Ottoman Empire in the Sixteenth Century»: H. Beinart (ed.), Moreshet Sepharad, II, Jerusalem 1992, pp. 109-133: 110.

${ }^{11}$ Estas indústrias prosperaram por muitos decénios, mas no final do século XVI ressentiram-se da forte concorrência dos países ocidentais. Cf. B. BRAUDE, «The Rise and Fall of Salonica Woolens, 1500-1650»: Mediterranean Historical Review 6 (1991), pp. 216-36.

12 J. HACKER, «The Sephardim in the Ottoman Empire in the Sixteenth Century», op. cit, p. 169.

${ }^{13}$ G. Veinstein, «L'Empire Ottoman depuis 1492 jusqu'à la fin du XIX ${ }^{\mathrm{e}}$ siècle»: H. Méchoulan (ed.), Les Juifs d'Espagne, Histoire d'une Diaspore, 1492-1992, Paris 1992, pp. 361-387: 377-79. 
bons olhos a fixação em novas localidades de indivíduos laboriosos que eram considerados fiéis às autoridades centrais. A partir de Salonica, mercadores e empreendedores hebreus difundiram-se capilarmente por todas as principais povoações da Moreia (Peloponeso) e da Grécia continental e, pouco a pouco, tomaram o lugar dos mercadores genoveses, florentinos e venezianos no comércio das matérias-primas balcânicas e na importação e distribuição das manufacturas italianas ${ }^{14}$.

Veio assim a formar-se uma rede de comunidades judaico-portuguesas distribuída por uma vasta área geográfica que se estendia para norte, no interior balcânico, até à bacia do Danúbio, para oeste, ao longo dos percursos das caravanas que de Salonica conduziam à costa adriática oriental através de Sarajevo, Monastir (Bitola), Uskub (Skopie) até alcançarem várias localidades portuárias do Adriático como Valona (Avlonya) ${ }^{15}$, Split, Narenta, Alessio e a cidade-república de Ragusa (Dubrovnik), onde nasceram - ou se desenvolveram - importantes escalas de trânsito. Também as colónias hebraicas de Corfu, de Zante e de outras ilhas iónicas sob domínio veneziano, engrandeceram no seguimento da emigração sefardita ${ }^{16}$.

Em redor de meados de Quinhentos, as cidades mercantis italianas consideraram os hebreus "levantini" como parceiros imprescindíveis no comércio transadriático ${ }^{17}$. A crescente importância das colónias mercantis hebraicas, nas duas margens do Adriático, está perfeitamente simbolizada na difusão de uma figura até então desconhecida: o cônsul da Nação Hebraica ${ }^{18}$.

Uma relação lavrada pelos Cinque Savi alla Mercanzia (uma espécie de ministério do comércio externo), em 1571, fornece notícias importantes sobre a dimensão das actividades empreendidas pelos mercadores do Ghetto ${ }^{19}$. A par das importações de zambelloti, peles e cera (até então isentas de direitos de entrada), os "levantini" exportavam grandes quantidades de fazendas de lã, tanto de

${ }^{14}$ A. Rodrigue, «The Sephardim in the Ottoman Empire»: E. Kedouri (ed.), Spain and the Jews: The Sephardi Experience: 1492 and after, London 1992, pp. 162-188; J. I. IsRAEL, European Jewry in the Age of Mercantilism, 1550-1750, Oxford 1985, p. 37.

${ }^{15}$ G. Veinstein, «L'Empire Ottoman...», op. cit., pp. 365-67.

${ }^{16}$ A. Seymour, «Les Sepharades de Corfou et des autres îles ioniennes»: H. MÉchoulan (ed.), Les Juifs d'Espagne, op. cit., pp. 332-344.

17 J. I. IsRael, Diasporas within a Diaspora, Jews, Cripto-Jews and the World Maritime Empires (1540-1740), Leiden-Boston-Köln 2002, pp. 9-10.

18 A. di Leone Leoni, «Una Teshuvà del Ma”harashdam di Salonicco...», op. cit., pp. 143-192: 160-161.

${ }^{19}$ ASVe, CSM, registro 136, 10.12.1571. 
produção veneziana ${ }^{20}$ como ocidental, procurando assim uma importantíssima receita fiscal. Outras receitas de monta provinham dos direitos de saída pagos pelos levantinos ${ }^{21}$ sobre as suas reexportações de produtos balcânicos para os domini di terra de Veneza, as outras regiões italianas e a Europa Ocidental.

É interessante notar que, entre as mercadorias importadas do Levante, estava a pimenta, um produto que há alguns decénios os mercadores hebreus conseguiam fazer chegar de novo a Veneza desde o Mediterrâneo Oriental, enquanto que, na primeira metade do século, os Estados italianos tinham sido obrigados a adquiri-lo a partir de Portugal, na praça de Antuérpia.

A risposta dos Sábios junta-se à documentação já disponível e fornece uma confirmação inegável de que, na segunda metade de Quinhentos, os mercadores hebreus aprovisionavam Veneza com pimenta, especiarias, pérolas, telas e tecidos orientais ${ }^{22} \mathrm{e}$ outros produtos do Oriente ${ }^{23}$, seja por via terrestre, a partir de Alepo (onde chegavam, através do percurso das antigas rotas caravaneiras, passando por Bassorá-Bagdad), seja por via marítima, a partir do Cairo ${ }^{24}$ e de Alexandria do Egipto (que os recebia através do Oceano Índico e do Mar Vermelho) ${ }^{25}$. Havia ainda outros carregamentos de especiarias que eram encaminhados por terra até

${ }^{20}$ Entre os tecidos venezianos mais procurados estavam seguramente os de cor "scarlattino" e carmesim, que foram imitados também pela indústria de Ferrara. Sobre o desenvolvimento da indústria têxtil de Veneza no século XVI, cf. Pompeo G. Molmenti, La Storia di Venezia nella Vita Privata, II, Lo Splendore, Bergamo 1927, p. 161.

${ }^{21}$ Os privilégios comerciais dos judeus haviam sido oficialmente concedidos aos judeus levantinos, súbditos do Turco, com a exclusão dos judeus alemães e italianos. Desta forma, os funcionários da administração estatal, e de modo particular os oficiais da Alfândega, definiam globalmente como "levantini" todos os mercadores hebreus, pese embora soubessem que entre eles havia muitos portugueses.

${ }^{22}$ Sobre a extraordinária variedade e tipologia dos tecidos importados do Império Otomano, veja-se G. Curatola: «Tessuti ed Artigianato Turco nel Mercato Veneziano»: Aa.vv., Venezia e i Turchi: scontri e confronti di due civiltà, Milano 1985, pp. 38-55: 41-42.

${ }^{23}$ B. Arbel, Trading Nations..., op. cit., pp. 67-68; A. di Leone Leoni, «Una Teshuvà del Ma"harashdam di Salonicco...», op. cit., pp. 161-162.

${ }^{24}$ Cf. Ugo Tucci, «Tra Venezia e Mondo Turco: I Mercanti»: Aa.vv., Venezia e i Turchi: Scontri e Confronti di Due Civiltà, Milano 1985, pp. 38-55.

${ }^{25}$ F. C. LANE, «The Mediterranean Spice Trade, its Revival in the Sixteenth Century»: IDEM, Venice and History, the Collected Papers of F. C. Lane, Baltimore 1966; H. KelLENBENZ, «Venedig als internationales Zentrum und die Expansion des Handel im 15. und 16. Jahrhundert»: H. G. BЕск (ed.), Venezia, Centro di Mediazione tra Oriente e Occidente, Firenze 1977, I, pp. 281-305: 290-291; J. I. Israel, Diasporas within a Diaspora, op. cit., p. 69. Sobre a importância comercial das colónias hebraicas do Cairo e de Alexandria do Egipto, cf. J. LE Goff «L'Italia fuori dell'Italia»: Storia d'Italia, vol. 2**, Dalla Caduta dell'Impero Otomano al secolo XVIII, Giulio Einaudi Edit., Torino 1974, pp. 2168-2169; U. TuccI, «Tra Venezia e Mondo Turco: I Mercanti», op. cit., pp. 38-55: 41. 
Istambul e daí, através dos Balcãs, até aos terminais portuários de Ragusa ${ }^{26}$, de Narenta e de Alessio ${ }^{27}$ (e, a partir de 1589, de Split).

Este fenómeno foi digno de registo nos diários de viagem de algumas personagens ilustres. No seu famoso Itinerário da Terra Santa, Frei Pantaleão de Aveiro referiu ter encontrado, em Damasco, Tripoli e Alepo, mercadores judeus de origem (e de língua) portuguesa ${ }^{28}$ que importavam especiarias e artigos de luxo da Índia, através da antiga estrada de Bagdad ${ }^{29}$.

A partir das memórias da viagem de Hans Dernschwam ${ }^{30}$ sabemos que a empresa comercial gerida por Grácia Naci, alias Beatriz de Luna, e Joseph Naci, alias João Micas, exportava para Veneza e para outras cidades italianas lã [em rama, balcânica], pimenta e cereais. Dona Grácia $\mathrm{Naci}^{31}$ desempenha neste campo um papel pioneiro, porquanto fornece a Veneza, desde 1555, quantidades assinaláveis de pimenta e de cereais, objecto de grande procura ${ }^{32}$.Como é sabido, a Senhora tinha deixado Veneza, no Verão de 1552: no decurso de apenas dois anos, não apenas se havia inserido, de forma notável, no tradicional comércio

${ }^{26}$ Ragusahavia sidoescolhidapor Dona Grácia como aúnica escala de trânsitonas suas actividades comerciais transadriáticas. Cf. J. TADIć, Jevreji u Dubovniku do polovine XVII stolijeca, Sarajevo 1937. Um primeiro acordo quinquenal de exclusividade foi concluído em 1557 e renovado em 1562. Cf. H. Kellenbenz, «I Mendes, i Rodriguez d'Evora e i Ximenes nei loro rapporti commerciali con Venezia»: G. CozzI (ed.), Gli Ebrei e Venezia, op. cit., pp. 143-161: 148.

${ }^{27}$ No seu testamento, redigido em 1589, David Membrech declarou aguardar a entrega de sete fardos de peveri da parte de Yomtob Cohen de Ragusa. Outras importantes remessas de peveri, também provenientes de portos dálmatas, estavam guardadas em dois armazéns, em Rialto.

${ }^{28}$ Cf. As Gavetas da Torre do Tombo, I, Lisboa 1960, p. 896, doc. 561, 7.8.1550: Carta de Frei António Soares a D. João III, na qual lhe dava notícia da sua peregrinação à Terra Santa e dos muitos judeus que lá achara, que se diziam portugueses.

${ }^{29}$ Frei Pantaleão de Aveiro, Itinerário da Terra Santa e suas particularidades, composto por Fr. P. de A., Lisboa 1593, fls. 235r-251v.

${ }^{30}$ Hans Dernschwam, Tagebuch einer Reise nach Konstantinopel und Kleinasien, a cura di F. BABINGER, Munich 1923, pp. 106 sqq..

${ }^{31}$ Gabriella Zavan, Gli ebrei, i marrani e la figura di Salomon Usque, Treviso 2004, pp. 148-149.

32 Ao envio recente de um navio de trigo e a outras remessas similares já preparadas por Dona Grácia, referiu-se Odoardo [Duarte] Gomes na sua deposição diante do Tribunal do Santo Ofício de Veneza, no dia 15.7.1555. Cf. ASVe, S. Uffizio, Processi, busta 159; P. C. Ioly Zorattini, Processi, vol. I, p. 232. Sobre a formação humanística e o magistério de Duarte Gomes, alias Salomão Usque, na Universidade de Lisboa, cf. A. M. L. Andrade, «A figura de Salomão Usque: a face oculta do humanismo judaico-português»: M. GonçALves et alii (eds.), Gramática e Humanismo. Actas do Colóquio de Homenagem a Amadeu Torres. Braga 2005, vol. II, pp. 15-25; sobre as actividades comerciais e sobretudo culturais desenvolvidas por Duarte Gomes e outros reputados humanistas portugueses desterrados em terras italianas, cf. A. M. L. ANDRADE, «Os Senhores do Desterro de Portugal: Judeus portugueses em Veneza e Ferrara em meados do século XVI»: Veredas, Revista da Associação Internacional de Lusitanistas 6 (2006), pp. 65-108. 
balcânico entre Veneza e o Levante, mas estava também em condições de fornecer grandes quantidades de mercadorias bastante procuradas e difíceis de encontrar ${ }^{33}$.

Os mercadores hebreus detinham, em geral, um papel de extraordinária importância no abastecimento de trigo à república de Veneza, já que importavam do Levante grandes quantidades deste cereal ${ }^{34}$.

Esta feliz situação foi interrompida, em 1570, quando Kubad, 'çavus' (mensageiro) da Grande Porta, trouxe a Veneza um ultimato do Sultão que intimava à entrega da ilha de Chipre ${ }^{35}$. Em vez de ceder a esta imposição, o governo da Sereníssima preferiu entrar numa guerra que os venezianos não desejavam.

\section{§ 2. A Guerra de Chipre}

Desde os primeiros dias da Guerra, o governo da Sereníssima mandou prender os mercadores turcos de religião islâmica e os judeus levantinos que, pelo menos convencionalmente, eram considerados súbditos do Turco. As suas mercadorias e bens, incluídos os títulos de crédito, acabaram por ser apreendidos. Foram excluídos expressamente da aplicação destas medidas os mercadores orientais de religião cristã ${ }^{36}$. A guerra de Chipre, que nasceu na sequência de disputas territoriais, apresentava também contornos claramente religiosos.

A tarefa de arrestar os bens dos súbditos inimigos havia sido confiada aos "Governatori delle Entrate", um órgão de polícia com funções administrativas e financeiras. Os seus agentes nem sempre fizeram uma distinção cuidadosa entre os hebreus levantinos e os outros mercadores que residiam no Ghetto de Veneza ou mesmo em Ferrara.

A aplicação prática desta medida provocou graves prejuízos a muitos mercadores que não eram súbditos do Turco. Na verdade, as autoridades venezianas apreenderam também as mercadorias que alguns judeus portugueses de Veneza e de Ferrara haviam adquirido a mercadores levantinos. Do mesmo

${ }^{33}$ M. Orfali ( «Doña Gracia Mendes and the Ragusan Republic»: E. Horowitz - M. Orfali (eds.), The Mediterranean and the Jews, Society, Culture and Economy in Early Modern Times, pp. 175-202: pp. 195-196), afirmou que Dona Grácia usou a sua influência em Constantinopla para assegurar o fornecimento regular de trigo à república de Ragusa.

${ }^{34}$ ASVe, CSM, Busta 62, Memoria Mercantile, n. 165, 17.9.1557: «Le grane che vengono in questa nostra città di Levante quasi tutte sono condutte da hebrei...».

${ }^{35}$ M. P. Pedani, In nome del Gran Signore, inviati Ottomani a Venezia dalla caduta di Costantinopoli alla Guerra di Candia, Venezia 1994, p. 162.

${ }^{36}$ B. Arbel, Trading Nations..., op. cit., pp. 23, 70-72. Para notícias posteriores, cf. A. di Leone LeONI, «La presenza sefardita a Venezia intorno alla meta del Cinquecento: I libri e gli uomini»: La Rassegna Mensile di Israel 67, n. ${ }^{\circ}$ 1-2. (2001), pp. 74-77. 
modo, foram confiscadas as letras de câmbio emitidas por mercadores levantinos em favor de judeus portugueses ou italianos.

A este título, é particularmente significativa a situação de Ser Iosué, filho do falecido Iacuda ${ }^{37}$ de Corfu, uma ilha sob soberania veneziana, que não podia ser considerado, em razão disso, um cidadão inimigo. No entanto, em Outubro de 1571, Iosué lamentou «i tempi strani della guerra» em que tinham sido apreendidas mercadorias pertencentes a seu pai, entre as quais havia pelo menos 800 cordovões.

Moises Cohem, filho de Isacco de Tripoli, que não era propriamente levantino, viu a sua propriedade sequestrada ${ }^{38}$. Os portugueses de Veneza e, em alguns casos, também os de outras cidades não puderam mais cobrar os seus créditos sobre os mercadores "levantinos" ou a esses assimilados ${ }^{39}$.

Os judeus portugueses que viviam no Ghetto de Veneza não foram directamente afectados, mas ressentiram-se do clima hostil a todos os "infedeli" e, em particular, aos hebreus. A hostilidade em relação aos judeus teve a sua manifestação mais notória na decisão do Senado de expulsar todos os judeus da cidade. O decreto, porém, não teve uma aplicação prática, se bem que, como é bom de ver, tenha gerado um clima de graves tensões e incertezas ${ }^{40}$.

Durante a guerra, os portugueses de Veneza intervieram, com frequência, em favor dos seus correligionários levantinos detidos. A título de exemplo, recorda-se o seguinte caso: em Dezembro de 1570, Gabriel de Negro concedeu aos Governatori delle Entrate a sua própria piezaria ${ }^{41}$ em favor do mercador levantino Suva, filho do falecido Abraham Cone da Larta, e entregou uma caução de cinquenta ducados de ouro como garantia da sua libertação dos "Gabbioni”, onde Suva se encontrava prisioneiro ${ }^{43}$.

${ }^{37}$ Iacuda tinha sido cônsul da Nação Hebraica de Corfu .

${ }^{38}$ Assim se depreende de um acto notarial lavrado em Ferrara, em 1574: ASFe, not. Giacomo Conti, Busta 14, 13.8.1574.

${ }^{39}$ Ibidem, 13.8.1574: João Lopes de Leão, mercador português de Ferrara, encarrega [o seu irmão] Iuda Abudiente, residente em Veneza, de reclamar todos os seus créditos a Moise Cohem, directamente ou por intermédio dos Governatori delle Entrate de Veneza.

${ }^{40}$ Sobre a promulgação do decreto e a sua suspensão no fim da guerra, veja-se B. ARBEL, Trading Nations..., op. cit., pp. 87-94.

${ }^{41}$ Piezaria $($ de pejo) $=$ fiança, caução, garantia pessoal .

${ }^{42}$ Gabbioni significa literalmente 'gaiolas grandes'. Foram assim designados, à época, os edifícios que as autoridades venezianas se viram obrigadas a utilizar, a título provisório, como prisões, durante a Guerra de Chipre. É provável que, à época, tenham sido construídas também algumas construções de carácter rudimentar e provisório, já que no período subsequente não há mais notícia dos referidos gabbioni.

${ }^{43}$ ASVe, not. G. B. Monti, 25.5.1573. 
Alguns portugueses de Ferrara deslocaram-se a Veneza com o objectivo de conduzir «in salvo» para o ducado estense as famílias ${ }^{44}$ dos levantinos detidos, que não poucas vezes estavam ligadas por relações de parentesco aos homens da Nação da cidade estense.

De entre as presenças mais notadas no Ghetto de Veneza, no tempo da guerra, convém recordar o caso de Mira Anriques ${ }^{45}$, a filha daquele Agostinho que havia já enfrentado dois processos inquisitoriais de que fora absolvido por acção da intervenção diplomática ${ }^{46}$ exercida em seu favor pela Grande Porta.

Os portugueses de Ferrara continuaram a gozar do privilégio, concedido à sua Nação, de poderem frequentar a praça de Rialto, embora com a condição obrigatória de terem de passar a noite no Ghetto ${ }^{47}$.

A protecção atribuída de forma tácita pela Sereníssima aos Portugueses de Veneza e aos de Ferrara, temporariamente presentes na cidade lagunar, encontra uma justificação evidente e compreensível no desejo da Sereníssima de retomar e potenciar, o mais rapidamente possível, as relações comerciais com o Levante, assim que acabasse a guerra. É sob esta óptica que deve ser perspectivado o projecto, aprovado pelo Conselho dos Dez, em 1573, quando a guerra não era ainda terminada, de convidar oficialmente para Veneza aqueles mesmos mercadores ponentinos ${ }^{48}$ em conjunto com os levantinos.

${ }^{44}$ Não dispomos de notícias sobre a sorte das famílias dos mercadores levantinos presos. Não parece, porém, que as suas mulheres hajam sido detidas. Em alguns casos, as famílias dos prisioneiros foram levadas para Ferrara, como se pode verificar, por exemplo, pelo testemunho de Moise Papo, filho de Abraam, relativamente a Abram Allalvo e Abram Abensusan, em ASFe, Canc. Ducale, Arch. per Materie, Ebrei, Busta 1, Processi, fascicolo N. 74.

${ }^{45}$ ASVe, not. G. B. Monti, reg. 8262, 7.5.1572: Mira Anriques, aqui identificada na qualidade de filha de Abraham Benvenisti [alias Agostinho Anriques/Henriques], nomeia como seu procurador Don Ysac Abravanel [filho de Don Yoseph e genro do falecido Don Samuel]. O acto foi passado em Veneza, no "Gheto Vetero", na residência do português Ser David Cid.

${ }^{46}$ Cf. G. Zavan, Gli ebrei, i marrani ..., op. cit, pp. 14-15.

47 ASMo, Cancelleria Ducale, Ebrei, Busta 1, Processi, N. 74: depoimentos prestados no Palácio da Justiça de Ferrara entre Janeiro e Fevereiro de 1573: Moise Papo, filho de Abraam, Giacomo Conti (notário em Ferrara), Jacob Molfo, Abraam de Bondi, Rabino e Doutor da Lei da Nação Portuguesa, Yoseph [Navarro alias] Pignero, Abram Verdai, Agostino Henriches, Samuel Coen, Isaac filho de Benedetto Benafrai, Joannes Lopes [neto de Gaspar Ribiera] e outros, pp. 2-33; requisitório de G. B. Bertazzoli, advogado de Abram Allalbo e Abram Abensusan, de 6.2.1573, perante o Tribunale del Comune de Ferrara, pp. 55-58. Cf. A. di Leone Leoni, «La Presenza Sefardita a Venezia...», op. cit., pp. 69-77.

${ }^{48}$ Ponentinos = Ocidentais, aqui usado para não indicar explicitamente o termo "Portoghesi" que, em Itália, na segunda metade do século XVI, se tornou sinónimo de cristãos-novos judaizantes e, por isso, podia não ser do agrado da Inquisição. 
Malgrado a vitória alcançada na famosa batalha de Lepanto, a Sereníssima acaba por sair derrotada do conflito. A ilha de Chipre não foi reconquistada. O custo da guerra e da paralisação das actividades mercantis (e, consequentemente, industriais) teve um efeito desastroso sobre a actividade produtiva. De facto, a ruptura das relações com o Levante conduziu ao encerramento da principal porta de saída da produção industrial. A Sereníssima pediu e acordou com o Império Otomano uma paz separada que, na realidade dos factos, representava uma meia rendição.É que Veneza renunciou à sua soberania sobre a ilha de Chipre e fez algumas pequenas, mas significativas, concessões territoriais na margem oriental do Adriático. Em geral, os historiadores italianos não têm, pudicamente, prestado muita atenção a esta paz não muito gloriosa. A Sereníssima justificou o seu comportamento aos seus aliados da Santa Liga com um longo memorial em que são apresentadas as suas motivações ${ }^{49}$.

\section{§. Algumas notícias sobre Daniel Rodriga}

Daniel era um ex-marrano português ${ }^{50}$ que chegou a Itália pelo final dos anos 50 ou início dos anos 60 . Alternou a sua presença na cidade estense com estadias no ghetto de Veneza, em Ancona e em várias localidades da costa da Dalmácia. Em todos estes lugares, definiu-se quase sempre como hebreu levantino. No entanto, em 1603, ditou o seu testamento em língua portuguesa ${ }^{51}$, permeado por numerosas expressões típicas da linguagem judaico-hispânica ${ }^{52}$.

${ }^{49}$ Biblioteca Ambrosiana, Milano, Ms. G 122 inf., fls. 21r-23v: «Ragioni della tregua fatta da' Veneziani col Turco l'anno 1573»; ibidem, fls. 83r-108v: «Ragioni in defesa de' Veneziani per esserci ritirati dalla lega contro il Turco l'anno 1573».

${ }^{50}$ Daniel Rodriga era originário da cidade de Bragança, na região de Trás-os-Montes, em Portugal. Cf. P. C. Ioly Zorattini, Processi, XIII, p. 19. Veja-se também, a este propósito, o testemunho elucidativo prestado por escrito por Frei Zacarias de Lisboa, no dia 14 de Setembro de 1594, ibidem, pp. 192-201: 192-93.

${ }^{51}$ ASVe, Notarile Testamenti, B. 347, not. G. A. Catti, Testamento 159. No apêndice documental, apresenta-se a análise e transcrição integral do testamento de Daniel Rodriga (documento 1).

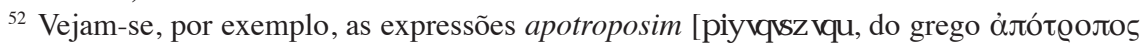
= administradores, executores testamentários]; apotroposimud [o exercício das funções de apotropos]; capara [f V V= expiação]; Hazaqah [ $\mathrm{fUjZ}$ dialecto judaico-italiano = posse, neste caso, direito adquirido de habitar um imóvel]; quetuba [fV V= escritura, contrato nupcial]. 
Segundo Renzo Paci ${ }^{53}$, Daniel terá iniciado a sua actividade de mercador em Ancona, onde, em 1549, operava em sociedade (?) com o irmão (? $)^{54}$ Petrus Dieghi Rodriguez, de quem não conhecemos o eventual nome hebraico ${ }^{55}$, e com Yoseph Hoef Falcon ${ }^{56}$.

Daniel, «filius quondam Moysii», habitou durante um certo período em Ferrara, no bairro de S. Agnese, na vizinhança da Sinagoga Portuguesa. Em 1562, confiou a Salamon d'Alva ${ }^{57}$ o encargo de efectuar a cobrança de alguns dos seus créditos na praça de Rialto. À época, os notários de Ferrara usavam uma linguagem muito precisa e calibrada que reflectia a posição económica e social dos seus clientes. Andrea Coccapani descreveu Daniel como «discretus vir», ou seja, como uma pessoa, em suma, bastante modesta. Todavia, o mandato atribuído a Salamon d'Alva era bastante amplo e articulado e denota uma certa variedade de interesses. De facto, Salamon estava habilitado a levantar dinheiro de qualquer

${ }^{53}$ R. PACI, La "Scala" di Spalato e il commercio veneziano nei Balcani fra Cinque e Seicento, Venezia 1971, p. 49.

${ }^{54}$ No seu testamento, Daniel Rodriga indicou como herdeiros «as filhas do irmão Jacob Rodriga €] X e «Moses, filho de Isaque €] X, sobre quem não estamos em condições de fornecer outras notícias. Aparentemente, a tradicional fórmula augural €] $X=$ que o seu Protector e Redentor o (talvez, neste caso, os) conserve] normalmente usada para as pessoas vivas, não se refere aqui aos irmãos de Daniel, mas aos seus filhos.

55 ASAn, not. G. B. Agli, reg. 224, 16.4.1549: acto de constituição de uma sociedade entre Yoseph Falcon de Hispania, de uma parte, e Daniel Barochum [=Barochas, non Rodrigas] e Petrus Dieghi Rodrighes, de outra. Petrus aparece como sócio de Daniel Barochas. Com efeito, pouco antes, o mesmo notário (ibidem, fl. 229v) registara uma Declaratio Societatis entre Daniel Barochas e "Petrum Rodrigum de Yspania". O nome de Daniel Rodriga não é mencionado em nenhum dos dois actos, pelo que não é possível estabelecer, com base nestes documentos, se havia entre Petrus e Daniel Rodriga, de facto, alguma relação de parentesco.

${ }^{56}$ Sobre esta figura, cf. A. di LeONE Leoni, «Per una Storia della Nazione Portoghese ad Ancona e a Pesaro»: P. C. Ioly ZorattinI (ed.), L'Identità Dissimulata: Giudaizzanti Iberici nell'Europa Cristiana dell'Età Moderna, Firenze 2000, pp. 27-97: 90, 93. Yoseph era, provavelmente, o pai do mártir Abraham Falcon morto num dos autos-de-fé celebrados em Abril de 1556. Ariel ToAfF, «Nuova luce sui Marrani di Ancona (1556)»: Ariel ToAfF et alii (eds.), Studi sull'Ebraismo Italiano in memoria di Cecil Roth, Roma 1974, pp. 261-80: 265. Cf. ASAn, reg. 224, fls. 49v-50r: Venditio equi Abrae Joseph Oef de Ispania.

57 Trata-se de Salamon Junior, filho daquele Salamon d'Alva que tinha sido correspondente e representante da Câmara Ducal de Ferrara, em Ancona e Pesaro, nos anos cinquenta. Num acto do notário G. B. Monti, de 28.9.1563, (ASVe, Notarile Atti, reg. 8250) é definido como «Salamon filius quondam alterius Salamonis». Salamon d'Alva Senior morreu em Veneza, em 1561 (ASVe, not. G. B. Monti, reg. 8249, 20.8.1562), depois de ter vivido muito tempo em Ancona, onde se identificava, regra geral, como judeu português. Cf. ASAn, not. Giovan Battista Agli, reg. 224, 4.11.1549; Ibidem, reg. 205, sub indice. 
banco ou banqueiro de Veneza, a estabelecer contactos com qualquer repartição pública ou magistrado, a cobrar e negociar letras de câmbio ${ }^{58}$.

Nos anos subsequentes, Daniel Rodriga mostrou-se bastante activo em diversas localidades da costa adriática oriental e adquiriu um profundo conhecimento daquele território espartilhado por tão grande número de pequenos domínios e enclaves de dependência e sujeição muito diversa. Daniel estabeleceu-se em Narenta, uma pequena cidade portuária em território otomano, não longe de Split, servida por boas ligações viárias com o interior ${ }^{59}$. Graças às suas boas relações com as autoridades turcas e com os senhores dos pequenos estados circunvizinhos, o judeu brigantino alcançou a tutela dos interesses da comunidade sefardita de Narenta. A partir daí, organizava a expedição de mercadorias balcânicas para Veneza ${ }^{60}$, por conta dos compatriotas que o haviam elegido cônsul. As suas funções consistiam, principalmente, na salvaguarda dos interesses daqueles que representava junto da administração local. Na qualidade de cônsul, Daniel desempenhava, de algum modo, as funções de notário público, porquanto era ele quem redigia a documentação necessária à expedição da carga (bill of lading) em conjunto com os capitães dos navios, certificando assim a qualidade e a proveniência das mercadorias. Além disso, o cônsul tinha de certificar-se de que os funcionários alfandegários, no interesse daqueles que representava, aplicavam efectivamente as taxas mais favoráveis.

Entre 1569 e 1570, Daniel Rodriga residiu no ghetto de Veneza onde continuou a usar o título de consul in oppido Narente ${ }^{61}$. Este cargo concedia-lhe, decerto, uma certa notoriedade, mas não a riqueza ${ }^{62}$. A partir de um documento redigido em Veneza, em $1569^{63}$, ficamos a saber que, por ocasião de uma anterior estadia na cidade lagunar, Daniel Rodriga, cônsul em Narenta, tinha contraído um débito de 340 ducados com Abraham Benvenisti [alias Manuel Henriques], um judeu português que vivia entre Ferrara e Veneza ${ }^{64}$.

${ }^{58}$ ASFe, not. Andrea Coccapani, matr. 534, pacco 10, 27.4.1562.

${ }^{59}$ R. PACI, La “Scala” di Spalato, op. cit., p. 50.

${ }^{60}$ Idem, Ibidem.

${ }^{61}$ ASVe, not. G. B. Monti, reg. 8257, fl. 30r, 19.10.1569.

${ }^{62}$ R. PACI, La “Scala” di Spalato, op. cit., pp. 50-51.

${ }^{63}$ ASVe, not. G. B. Monti, reg. 8256, 23.9.1569.

${ }^{64}$ Abraham [alias Manuel Henriques] filho de Mayr Benvenisti [alias Henrique Nunes, morto em Ferrara, em 1555] e de Reina Benvenisti [alias Marchesa Enriques], que à época vivia no Ghetto Vecchio. Cf. ASFe, not. P. Fiornovelli, Matr. 547, pacco 3, cópia de um documento redigido por um Bet Din Sefardita, de Veneza, em 5.7.1565; ASVe, not. G. B. Monti, 26.6.1567; ASFe, not. G. Conti, Matr. 584, pacco 14S, 22.7.1568.

Nos anos sessenta do século XVI, outros dois membros da família Henriques-Benveniste empregavam o nome Abraham. Referimo-nos a Agostinho Henriques e a Henrique Nunes, filho 
Um acto notarial, passado em Outubro de 1569, revela o empenho do cônsul de Narenta na boa cobrança de um crédito seu que teve origem num giro de letras de câmbio entre Ancona e Veneza ${ }^{65}$.

Em15deFevereirode 1570,Daniel Rodriga encarregou o mercadorDavidCohen de cobrar alguns dos seus créditos ${ }^{66}$, embora já não se intitule, nesta ocasião, cônsul de Narenta.É muito provável que tenha abandonado este título, associado directamente a um território sob o domínio de uma potência estrangeira, a fim de não ferir a sensibilidade das autoridades venezianas.

Durante a sua permanência em Veneza, Daniel Rodriga continuou a empreender negociações com importantes personalidades da Sereníssima a quem propunha - com sucessivas modificações e variantes - o projecto de criar um porto franco numa das numerosas colónias venezianas na costa da Dalmácia ${ }^{67}$. É assim que, por exemplo, ele próprio solicita o apoio da Senhoria, em 1569, para estabelecer uma praça comercial na cidade de Zadar (em língua italiana, Zara) e autorizar os mercadores portugueses a estabelecer-se nesse local ${ }^{68}$.

Em Veneza, Daniel Rodriga apresentava-se como um judeu levantino, mas não há notícia de que tenha sido preso no decurso da guerra de Chipre (1570-1573). Em Julho de 1570, encontrava-se em Ancona, onde se encarregou de obter o resgate de um jovem cristão, aprisionado pelos Turcos na costa oriental do Adriático, durante a guerra ${ }^{69}$.

Niccolò prometeu a Daniel o reembolso das despesas e um prémio de trinta ducados, um valor bastante modesto para os riscos que a missão comportava. Um não melhor identificado Rabbi Yoseph Amigo ${ }^{70}$ serviu de intermediário e garantiu que o prémio seria pago, mal o jovem prisioneiro conseguisse alcançar Ragusa ou outra terra em poder dos cristãos.

de Nuno Henriques [alias Senior Benvenisti] e de Violante [alias Velida], irmã de Reina [alias Marquesa] e tio daquele Abraham que, em 1569, era credor de Daniel Rodriga. O jovem Righetto foi protagonista de um famoso processo inquisitorial, em Veneza e Lisboa. P. C. IoLY ZoratTinI dedicou a esta figura um volume completo (Processi III, 1570-1572).

${ }^{65}$ ASVe, not. G. B. Monti, reg. 8257, 19.10.1569: «Ser Daniel Rodrigha hebreus levantinus Consul in oppido Narente, filius Ser Moysis» nomeia como seu procurador o "Magnificum Dominum" Nicola Cruce.

${ }^{66}$ ASVe, not. G. B. Monti, reg. 8258, sub data.

${ }^{67}$ A concessão da parte do Doge Mocenigo da carta-patente de 1573, de que falamos mais adiante, deixa perceber que Daniel Rodriga gozava de importantes apoios.

${ }^{68}$ ASVe, not. G. B. Monti, reg. 8256, 8.11.1569.

${ }^{69}$ R. PACI, La “Scala” di Spalato, op. cit., p. 49.

${ }^{70}$ ASAn, not. G. B. Agli, vol. 214, fls.101v-102r, 1.6.1570. Não sabemos se se trata do mesmo Yoseph Amico, «ebreo suddito del Turco», que, em 1567, em Veneza, fez parte de um colégio de quatro juízes encarregados de resolver um diferendo entre Hayim Saruc e Yoseph di Secura. Cf. B. Arbel, Trading Nations..., op. cit., p. 135. 
Os contactos de Daniel Rodriga com o governo veneziano interromperam-se, por certo, no início do conflito, mas foram rapidamente reatados. Durante as últimas fases da guerra, quando Veneza estava já a negociar uma paz em separado com o Império Turco ${ }^{71}$, a Senhoria começou a preocupar-se em restabelecer os laços comerciais com o Levante, sobre os quais se havia alicerçado a economia da cidade. É sobre este ângulo, seguramente, que deve ser vista a decisão tomada, em Janeiro de 1573, pelo Conselho dos Dez, em nome do Doge Mocenigo, de reconhecer e «confermare» a Daniel Rodriga o título de «Console della Natione Hebrea in questa città di Venezia», «quando che egli sia eletto», ou seja, antes que ele tivesse obtido essa nomeação da parte dos mercadores hebreus. Deste modo, através de um procedimento um tanto insólito, o Doge aprovava antecipadamente uma nomeação que Daniel não tinha ainda recebido e que, na realidade, naquele momento, não lhe foi atribuída.

Convém recordar que o Senado não havia ainda revogado a decisão de expulsar os judeus da cidade e dos seus domínios, tomada em 1571, no auge da excitação da vitória de Lepanto contra os infiéis ${ }^{72}$.

A nomeação de Daniel Rodriga estava decerto relacionada, no pensamento do legislador veneziano, com o projecto de convidar os mercadores ponentinos para virem estabelecer-se no ghetto de Veneza. No mesmo ano, o sanjaco de Clissa, provavelmente instigado por Daniel Rodriga, escreveu a Veneza, colocando a possibilidade de criar em Split um empório para as trocas veneto-otomanas ${ }^{73}$. Em Dezembro de 1573, o Conselho dos Dez emitiu, em nome do Doge, um salvo-conduto a favor dos judeus espanhóis e portugueses e de todas as pessoas de origem hebraica ${ }^{74}$. Muito seguramente, os projectos apresentados

${ }^{71}$ B. ARbel, «Venezia, gli Ebrei e l'attività...», op. cit., pp. 163-190: 175.

${ }^{72}$ AS Ve, Senato, Terra, filza, 58, 18.12.1571. Cf. B. RAVID, «The Socio-economic background of the Expulsion and Readmission of the Venetian Jews, 1571-1573»: F. MALINO - P. CoHEN (eds.), Essays in Modern History, a Tribute to Ben Halpern, London and Toronto 1982, pp. 50-51; B. Arbel, «Venezia, gli Ebrei e l'attività...», op. cit., pp. 163-190. Ravid julgou que o Senado tinha anulado o decreto de expulsão, tomando em consideração a importância que assumiam os empréstimos hebraicos, geridos pelos judeus "tudescos". Arbel, por sua vez, observou que as autoridades venezianas estavam mais preocupadas em restabelecer os laços comerciais com o Levante, interrompidos durante a guerra. A carta-patente de cônsul concedida a Daniel Rodriga demonstra claramente quais eram as intenções da Senhoria.

${ }^{73}$ R.PACI, «Gli ebrei e la "scala" di Spalato alla fine del Cinquecento»: G. CozzI (ed.), Gli Ebrei e Venezia, op. cit., pp. 829-834: 830.

${ }^{74} \mathrm{O}$ texto do salvo-conduto foi analisado e publicado, in extenso, em Zakhor, Rivista di Storia degli Ebrei d'Italia 2 (1998), pp. 91-93 e 103-105. 
por Daniel Rodriga exerceram uma influência determinante sobre a tomada desta decisão $0^{75}$.

Este salvo-conduto não foi aprovado pelo Senado [mas não é lícito supor, tão-pouco, que o projecto tenha sido discutido e reprovado]. De qualquer modo, a emissão das duas cartas-patentes marcou um ponto de viragem na política veneziana e a Sereníssima adoptou - ou talvez seja preferível dizer continuou - uma política de tolerância tácita para com os ex-marranos que, no interior do ghetto, viviam oficialmente como judeus ${ }^{76}$. Ao contrário do que se julgava, não está provado que Daniel Rodriga tenha sido eleito cônsul pelos mercadores hebreus de Veneza, seja em 1573, seja nos anos imediatamente seguintes. Por quanto se sabe até hoje, não existe documento algum que demonstre que ele haja ostentado este título, em Veneza, nos anos subsequentes à Guerra de Chipre. Não subsistem dúvidas, todavia, de que Daniel Rodriga actuou, de facto, como cônsul e representante da Nação Ponentina ${ }^{77}$ e da Levantina, a partir de 1589 , obtendo assim notáveis facilidades fiscais.

Convém que nos detenhamos, ainda um pouco mais, sobre a "nomina" feita pelo Doge Mocenigo, em 1573, uma vez que a citação menos cuidadosa deste documento, por parte de alguns estudiosos, fez surgir a convicção errónea de que naquela época existia [não só de facto, mas também] oficialmente, em Veneza, uma Nação Ponentina. O equívoco teve origem no facto de uma cópia da carta-patente estar conservada, em conjunto com outros documentos, numa pasta que um anónimo arquivista decidiu intitular "Hebrei Ponentini". Renzo Paci, o autor benemérito de um estudo pioneiro sobre a escala de Split, foi induzido a pensar que a nossa figura tivesse sido designada para representar a Nação Ponentina de Veneza. No entanto, porquanto houvesse ainda, em 1573, um certo número ${ }^{78}$ de judeus portugueses no Ghetto Vecchio $^{79}$, estes não tinham conseguido constituir uma "nação" autónoma ou, pelo menos, não era oportuno proclamar a sua existência. Alguns estudiosos julgaram mesmo que se tratava dos judeus

${ }^{75}$ B. Ravid, «The Venetian Government and the Jews», op. cit., pp. 3-30: 17.

${ }^{76}$ B. Pullan, The Jews of Europe and the Inquisition of Venice, 1550-1670, Oxford 1983, pp. 183-185.

77 A título de exemplo, em 1602, Daniel Rodriga requer aos Cinque Savi alla Mercanzia que a Nação Ponentina fique isenta de contribuir para a administração dos banchi di prestito dos judeus "tudescos". Cf. ASVe, CSM, reg. 141, fl. 23v, Risposta del 15 settembre 1602.

${ }^{78} \mathrm{O}$ número de portugueses residentes no Ghetto Vecchio tinha diminuído após o início da guerra, uma vez que muitos se transferiram para Ferrara.

${ }^{79}$ Sobre o importante núcleo de judeus espanhóis e portugueses estabelecido no Ghetto de Veneza, por volta de meados de Quinhentos, veja-se A. di Leone LeONI, «I Marrani di Coimbra...», op. cit., pp. 91-96 e docs. 6 e 12; IDEM, «Alcuni esempi di quotidiana imprenditorialità...», op. cit., pp. 97-103; IDEM, «La Presenza Sefardita a Venezia...», op. cit., pp. 69-77. 
Ponentinos da Dalmácia ${ }^{80}$. Na realidade, a carta-patente do Doge Mocenigo não deixa margem para dúvidas, quando regista claramente «Console della Natione Hebrea in questa nostra Città di Venetia» ${ }^{81}$.

Confirma-se a presença de Daniel em Veneza, no dia 18 de Abril de 1575, quando nomeou, como seu procurador, o cunhado Ysac de Casteris [Castro] que, por sua vez, lhe atribuiu idêntico mandato ${ }^{82}$. No dia 9 de Janeiro de 1576, Daniel Rodriga esteve presente na redacção de um acto notarial e prestou a sua garantia sobre a exacta identidade do mercador Ysaach Nahar ${ }^{83}$.

Como se sabe, em 1577, Daniel Rodriga apresentou à Senhoria o projecto de criar um porto franco, à semelhança do que já fora feito, desde 1542, nas ilhas de Corfu e de Zante, para reencaminhar para a nova Scala o comércio entre Veneza e o Levante ${ }^{84}$. O sucesso do plano tornar-se-ia possível apenas através da participação activa de cinquenta mercadores ponentinos que Daniel Rodriga se propunha acolher no Ghetto Vecchio.

Em 1579, os Cinque Savi alla Mercanzia examinaram uma nova petição de Daniel Rodriga, que havia solicitado a concessão de isenções aduaneiras para um grupo de mercadorias destinadas à exportação: as peles e os couros (em particular os cordovões) ${ }^{85}$ de procedência balcânica que os mercadores

${ }^{80}$ Cf. B. Crippa, A. Veronese, C. Vivante, (eds.), La Comunità Ebraica di Venezia e il suo Antico Cimitero, Ricerca a cura di Aldo Luzzatto, Milano 2000, Vol. II, Indice dei nomi, pp. 1054-1055, onde Daniel Rodriga é mencionado também como «presidente della Comunità Ebraica di Venezia», título que à época não existia, porque a compósita população do Ghetto de Veneza estava subdividida em duas (e depois em três) distintas «Nazioni». O anónimo redactor do Medaglione, Ibidem, Vol. I, p. 379, por sua vez, retomou a definição de Paci: «console degli ebrei ponentini».

${ }^{81}$ ASVe, CSM, B. 63, fascículo intitulado postumamente: "Ebrei Ponentini”.

${ }^{82}$ ASVe, not. G. B. Monti, reg. 8267, sub data.

${ }^{83}$ Ibidem, reg. 8268, 9.1.1576.

${ }^{84}$ C. Roth, The Jews in Venice, New York 1975 (reimpressão), pp. 305-306; IdEM, A History of Marranos, Philadelphia 1932, pp. 210-211; B. RAvID, «The First Charter of the Jewish Merchants of Venice»: Association for Jewish Studies Review, vol. I (1976), pp. 187-222; B. Arbel, «Jews in International Trade»: R. C. DAVIs - B. RAVID (eds.), The Jews of Early Modern Venice, op. cit, pp. 73-96: 86-88; B. D. CoOPERMAn, «Venetian Policy towards Levantine Jews and its broader Italian Context»: G. CozzI (ed.), Gli Ebrei e Venezia, op. cit., pp. 65-84: 74-77; P. C. Ioly Zorattini, Processi del S. Uffizio di Venezia contro Ebrei e Giudaizzanti, vol. VIII, 1587-1598, pp. 8-9.

${ }^{85} \mathrm{O}$ cordovão designava vulgarmente o couro de cabra curtido e preparado especialmente para o calçado, como evidenciam, por exemplo, as últimas palavras que o Sapateiro dirige ao Diabo, no Auto da Barca do Inferno de Gil Vicente, arrenegando o cordovão e a badana. Cf. G. Vicente, Auto de Moralidade da Embarcação do Inferno. Texto das duas primeiras edições avulsas e das Copilações estudados por Paulo Quintela, Coimbra 1946, 342-346. 
ponentinos, na eventualidade de serem acolhidos em Veneza ${ }^{86}$, reexportariam para a Europa Ocidental. A proposta obtém um parecer bastante favorável dos Cinco Sábios. Na sua Risposta, estes examinaram as facilidades aduaneiras obtidas pelos levantinos, entre 1514 e 1579, e verificaram que as reduções de taxas alfandegárias, concedidas no passado aos mercadores hebreus, se tinham traduzido, regra geral, em conspícuos aumentos do volume dos seus negócios, a contento da Sereníssima, que assim era aprovisionada de todo o género de mercadorias e registava um aumento constante da receita dos impostos. Os Cinco Sábios concederam o seu apoio à proposta de acolher cinquenta mercadores ponentinos, em Veneza, porquanto a sua actividade iria contribuir para desviar de Ancona para Veneza o tráfico transadriático. No entanto, o projecto de abrir as portas do ghetto aos judeus "ponentini" e de estabelecer uma directriz comercial entre Veneza e o Levante, através do porto franco de Split, apenas viria a ter a aprovação do Senado em $1589^{87}$.

Entre 1579 e 1589 (ou seja, quando o governo de Veneza não dava ainda sinal de querer realizar o projecto de Split), Daniel Rodriga passou longos períodos na costa oriental do Adriático e efectuou viagens frequentes entre os diversos portos da região, especialmente entre Narenta, Alessio, Durazzo, Valona, Ragusa e Ancona. $\mathrm{O}$ judeu brigantino pôs em prática vários projectos para fortalecer $\mathrm{o}$ comércio transadriático e para reforçar as colónias portuguesas disseminadas ao longo da costa e do interior balcânico.

Assinala-se, a título de exemplo, a petição enviada à república de Ragusa por Daniel Rodriga (cônsul de Narenta), em conjunto com Samuel Ergas e Salamon Oef, os dois cônsules hebreus da cidade ${ }^{88}$. Os três judeus portugueses solicitavam às autoridades ragusinas a redução de algumas taxas alfandegárias e comprometiam-se a intensificar o tráfico comercial através do porto da cidade, com um consequente aumento global das suas receitas.

${ }^{86}$ A petição estava relacionada com o projecto, já apresentado em 1577, de estabelecer uma escala de trânsito em Split.

${ }^{87}$ C. Roth, The Jews in Venice, op. cit., pp. 305-306; IDEM, A History of Marranos, op. cit., pp. 210-211; B. D. COOPERMAN, «Venetian Policy...», op. cit., pp. 65-84: 74-77; B. ArbeL, «Jews in International Trade», op. cit., pp. 73-96: 86-88.

${ }^{88}$ AHD, Acta Consilium Rogatorum, 3/67, fls. 125-127. Veja-se, em apêndice (doc. n. o 2), a transcrição integral desta petição, referenciada por J. TADIć, op. cit., p. 92, nota 19. 


\section{§ 4. A Nação Ponentina (=Portuguesa e Espanhola) de Veneza e a Escala de Spalato (Split)}

Em 1589, o Senado da Sereníssima acolheu favoravelmente a proposta avançada por Daniel Rodriga e emitiu a famosa condotta a favor das Nações Levantina e "Ponentina". Este salvo-conduto abriu as portas de Veneza aos mercadores portugueses e modificou o estatuto dos hebreus levantinos, que deixaram de ser mercadores estrangeiros, nominalmente em trânsito (viandanti), para se tornarem residentes estáveis, súbditos de Veneza e não mais do Turco, com a liberdade de residir, em permanência, no Ghetto, com as suas famílias.

A nova Nação Ponentina teve um crescimento fulgurante e transformou-se, de pronto, na componente mais influente da compósita comunidade hebraica veneziana. Além das trocas com o Levante, os mercadores judeus dedicaram-se ao comércio ibérico e estabeleceram estreitas relações com Amsterdão e Hamburgo.

Veneza foi durante muito tempo a capital cultural e espiritual do hebraísmo sefardita. Quando a Nação Portuguesa de Amesterdão adoptou uma estrutura unitária, inspirou-se no seu modelo.

A decisão de acolher em Veneza os ex-conversos ibéricos, tomada pelo Senado, estava ligada ao projecto apresentado por Daniel Rodriga de estabelecer em Split um porto franco, redireccionando o comércio com o Levante, por via terrestre, ao longo das rotas caravaneiras que da costa adriática conduziam a Salonica e a Constantinopla. A abertura da nova rota comercial transadriática e transbalcânica foi coroada de sucesso e reforçou o comércio veneziano com o Oriente, praticado em grande medida pelos mercadores hebreus. Daniel Rodriga foi reconhecido pelo Senado como "inventore della Scala di Spalato" e nomeado cônsul dos mercadores ponentinos e levantinos.

Em 20 de Julho de 1590, após a comprovação de que o projecto da "Scala di Spalato" estava destinado ao sucesso, o Senado emitiu uma parte segundo a qual os judeus levantinos e ponentinos, que futuramente se instalassem em Veneza, não seriam obrigados a contribuir para a tributação dos hebreus tudescos ${ }^{89}$. No referido decreto, foi inserida uma cláusula feita à medida de Daniel Rodriga «con suo fratello et genero $»^{90}$, como recompensa «dei molti benefici da lui recati alla Signoria». Ficou assim estabelecido que também podiam gozar do privilégio de 1589 todos aqueles que, no passado, houvessem já vivido em Veneza e regressassem após uma ausência de cinco anos.

${ }^{89}$ ASVe, CSM, busta 63; outra cópia, ibidem, busta 163. O documento foi publicado por A. di Leone Leoni, «Una Teshuvà del Ma”harashdam...», op. cit., p. 189.

${ }^{90}$ O documento não regista o nome do irmão de Daniel nem o do "genero". 
Com o mesmo decreto, o Senado aprovou entusiasticamente a nomeação do «fedelissimo nostro» Daniel Rodriga como «Console degli Hebrei Levantini e Ponentini di questa città» ${ }^{91}$ e exonerou-o de contribuir para as taxas que os judeus tudescos estavam obrigados a pagar pela manutenção dos seus banchi ${ }^{92}$.

Tinham decorrido dezassete anos desde que o Doge Mocenigo lhe havia conferido a famosa patente a que já antes nos referimos. Vale a pena observar que, em 1589, o Senado rejeitou e não aprovou uma cláusula contida na proposta de Daniel Rodriga: não foi concedido, nem aos judeus de Split, nem àqueles que residiam no Ghetto de Veneza, autorização para abrirem negócios e lojas de artesãos. Em Veneza, os judeus sefarditas foram excluídos também do exercício da arte strazzaria ${ }^{93}$, reservado aos judeus ditos "tedeschi" que residiam no Ghetto Nuovo.

${ }^{91}$ Alguns investigadores julgaram que se tratasse da cidade de Split; na realidade, tratava-se de Veneza. De facto, a referência aos judeus "Tedeschi” e às despesas que estes suportavam para manter os seus banchi indica claramente que o documento se referia a Veneza. Convém referir, porém, que existe uma segunda versão deste documento, conservada em ASVe, CSM, Seconda Serie, Scritture in Materia Commerciale, Busta 44, fascículo intitulado "Memoria Mercantile 115, Console degli Ebrei a Spalato", no qual se afirma «Che il sopradetto Daniel Rodriga inventor della sopradetta Scala sia confirmato Console in quella Città della Nazione sopradetta dalla quale è stato eletto...». É lícito, portanto, considerar que Daniel Rodriga foi confermato Cônsul de Split, onde provavelmente já exercia há algum tempo esse cargo, e que foi também nomeado à época Cônsul da Nação, em Veneza. Daniel Rodriga exerceu este cargo pelo menos até 1602 (veja-se a parte final da nota seguinte). Por outras fontes, confirma-se que o judeu português desempenhou o mesmo cargo também em Split, em conjunto com o seu irmão Iacob e o cunhado Isac de Castro que, não raras vezes, o substituíram.

${ }^{92}$ Os judeus "tedeschi", que habitavam em conjunto com os italianos no Ghetto Nuovo, estavam obrigados a manter banchi di pegno e a conceder empréstimos com taxas de juro extremamente baixas. Nestas condições, a concessão de empréstimos tinha-se transformado numa espécie de instituição caritativa em apoio dos pobres da cidade. A gestão dos banchi apresentava constantemente prejuízos e era suportada por todos os judeus "tedeschi”, que estavam sujeitos ao pagamento de pesadas taxas pela sua Comunidade. No final do século XVI, os judeus levantinos aceitaram contribuir, em certa medida, para estas despesas. A esta temática, dedicou B. PullaN a sua obra La politica sociale..., op. cit..

Em 1602, Daniel Rodriga enviou uma petição ao Governo de Veneza, requerendo que a Nação Ponentina residente no Ghetto Vecchio fosse exonerada da contribuição para as despesas dos banchi (ASVe, CSM, Reg. 141, fl. 23v).

${ }^{93}$ Sobre o desenvolvimento desta actividade no século XVI, cf. B.PulLan, La politica sociale..., op. cit., pp. 605-606; A. di LEONE LEONI, «Alcuni esempi di quotidiana imprenditorialità...», op. cit., pp. 92-93. 


\section{§ 5. Para Lá de Split: Novos Sonhos e Novos Projectos}

A escala de Split desenvolveu-se com rapidez, não obstante as numerosas dificuldades de ordem técnica ${ }^{94}$ e burocrática ${ }^{95}$. Os esforços que Daniel Rodriga empreendeu, ao longo de quase vinte anos ${ }^{96}$, foram coroados de um amplo sucesso. No entanto, ele não repousou sobre os louros alcançados, pois continuou a efectuar novas pesquisas e a arquitectar projectos inovadores, que nem sempre estavam de acordo com a política da Sereníssima.

Na verdade, o Governo de Veneza via na constituição da escala de Split a solução dos seus problemas comerciais e, em consequência, propunha-se concentrar a totalidade do seu tráfico comercial com os Balcãs exclusivamente através da escala de Split, evitando assim recorrer aos portos rivais de Ragusa e a outras escalas na costa adriática oriental. Daniel Rodriga, pelo contrário, considerava Split apenas como o primeiro anel de uma cadeia mais vasta que deveria unir Veneza às várias "Nazioni Portoghesi" ao longo do Adriático e da costa da Moreia até Salonica ${ }^{97}$.

Não deviam ser estranhos aos projectos de Daniel Rodriga os frequentes desvios que as galere mercantes, envolvidas na ligação com Split, faziam para lá do seu destino oficial, até alcançarem os portos de Ragusa, Narenta, Valona, Arta e Durazzo.

Em 1596, Daniel Rodriga apresentou uma nova petição através da qual procurava instituir uma rota comercial para o porto de Durazzo e para Salonica. Os Cinque Savi alla Mercancia deram um parecer favorável, observando que o novo trajecto traria grandes vantagens à República, na medida em que iria aumentar a actividade comercial sem entrar em concorrência com a escala de Split, que não seria prejudicada ${ }^{98}$. Não obstante a aprovação desta proposta por parte dos Cinco Sábios, não parece que o Senado lhe tenha dado seguimento imediato.

Um ano volvido, Daniel Rodriga renovou o pedido com recurso a novos argumentos. Ele havia conseguido fazer aportar em Veneza dois navios

${ }^{94}$ ASVe, CSM, Busta 62, Memoria Mercantile 114: Spalato. Negocio per l'escavacione del porto e fabbrica del Lazzaretto e altro.

${ }^{95}$ Cf. B. RAVID, «Daniel Rodriga and the Jewish merchants of Venice»: A. MirsKY, A. Grossman, Y. KAPLAN (eds.), Exile and diaspora: studies in the history of the Jewish people presented to Professor Haim Beinart, Jerusalem 1991, pp. 203-223.

${ }^{96}$ Vide, supra, nota 82.

${ }^{97}$ ASVe, CSM, Risposte, Registri 138-140, passim.

${ }^{98}$ Ibidem, Reg. 139, 16.12.1596. 
flamengos carregados de sal $^{99}$, muito provavelmente de produção ibérica ${ }^{100}$, a um preço concorrencial em relação ao sal extraído das salinas da Dalmácia (sob domínio veneziano) ou de Comacchio (no Ducado Estense) ou de Cesena (na Romagna Pontificia). Daniel Rodriga propôs que os dois navios prosseguissem directamente para Salonica, instaurando (ou melhor, reabrindo) um novo caminho marítimo para o grande empório do Mar Egeu, oferecendo, além de mais, um novo produto bastante procurado nos Balcãs ${ }^{101}$. O novo percurso marítimo excluiria Ragusa e os outros portos do Adriático meridional, em prejuízo da escala de Ancona.

Daniel Rodriga estava convencido de que esta operação haveria de engrandecer o comércio de Veneza e reforçar a posição dos mercadores hebreus. Para realizar este projecto, o judeu português tencionava deslocar-se à Albânia (em particular a Durazzo) e à Grécia para estudar os problemas inerentes a esta nova empresa. Ele estava também disposto a assumir do seu próprio bolso as despesas desta viagem. No entanto, uma vez que não dispunha de imediato da soma necessária,

${ }^{99}$ Graças aos progressos da sua indústria naval, os holandeses adquiriram rapidamente uma posição de grande proeminência nas trocas comerciais com a Península Ibérica, mas também no transporte marítimo de todos os produtos destinados ou provenientes dos portos ibéricos, seja para a Europa do Norte, seja para a bacia do Mediterrâneo. Os transportes de lã e de sal assumiram uma importância particular. Gino LUZZATTO, «La decadenza di Venezia dopo le scoperte geografiche nella tradizione e nella realtà»: Archivio Veneto LIV-LV (1954), pp. 165-175, e mais em geral, IDEM, Storia Economica dell'Età Moderna e Contemporanea, Vol. I, Padova ${ }^{4} 1955$, pp. 246 sqq.; V. M. GodinHo, L'Economie de l'Empire Portugais aux XV et XVI' siècles, Paris 1969, pp. 817 sqq.; cf. A. di Leone Leoni, La Nazione Ebraica Spagnola e Portoghese negli Stati Estensi, Rimini 1992, pp. 19-27.

${ }^{100}$ Sobre a produção de sal em Portugal, continuam a ser fundamentais os vários trabalhos de Virgínia RAu, reunidos em Estudos sobre a História do Sal Português, Lisboa 1983. Os holandeses eram grandes consumidores do sal produzido nas solarengas salinas de Setúbal (Portugal) e de Cádis (Espanha), porquanto este produto era imprescindível tanto para o consumo directo como para a conservação de géneros alimentares perecíveis como o peixe ou a carne. De facto, o sal português tinha como destino principal os mercados do Norte da Europa. Já o sal que chegava a Veneza provinha de vários centros de produção mediterrânica, entre os quais Ibiza ocupava um lugar de grande destaque na segunda metade de Quinhentos. Para uma análise da importância do comércio do sal na economia veneziana, cf. Jean-Claude Hocquet, Le Sel et la Fortune de Venise, 2 vols., Lille 1982.

${ }^{101}$ Convém recordar que o sal era um produto imprescindível, não só para o consumo humano e para as indústrias alimentares, mas também para a alimentação dos próprios animais, em particular das bestas de carga - cavalos e camelos - que transportavam as mercadorias através das rotas caravaneiras que atravessavam os Balcãs. Havia, por isso, armazéns de sal destinados a fornecer os animais das caravanas em vários portos adriáticos orientais como Split, Ragusa ou Alessio. Para uma análise quantitativa das necessidades de sal por parte do homem e dos animais, cf. J.-C. Hocquet, Le Sel et le Pouvoir. De l'An Mil à la Revolution Française, Paris 1985, pp. 361-368. 
solicitou à Sereníssima que lhe adiantasse 3.200 ducados à conta de muitas (as dezasseis restantes) prestações anuais de 200 ducados que a Sereníssima lhe havia concedido como prémio pela «invenzione» da escala de Split. Em alternativa, o diplomata brigantino pede um empréstimo de 10.000 ducados para financiar esta prospecção ${ }^{102}$.

Daniel Rodriga tencionava recuperar ao menos uma parte das suas despesas com a imposição de uma pequena comissão sobre as expedições para Salonica, assim que o novo trajecto marítimo fosse iniciado. Estamos em crer que este verdadeiro diplomata português foi movido não tanto pela perspectiva um pouco incerta de lucro pessoal ${ }^{103}$ quanto por um novo desafio, pela sua costumada paixão pelas grandes empresas, ainda que difíceis e perigosas, e, sobretudo, pela sua profunda dedicação à própria Nação, a quem desejava oferecer novas possibilidades empresariais, sabendo perfeitamente que os judeus portugueses haveriam de encontrar asilo e hospitalidade, pelo menos naqueles países que fossem beneficiados com as suas actividades económicas.

Os Cinco Sábios aprovaram com entusiasmo a proposta de Daniel Rodriga, mas não estamos em condições de estabelecer, no estado actual da investigação, se esta iniciativa teve um seguimento prático e efectivo.

As tentativas para reforçar as relações com os núcleos portugueses espalhados ao longo das costas do Mediterrâneo não afastaram a atenção de Daniel Rodriga dos problemas relativos à escala de Split. Entre 1590 e 1599, ele apresentou diversas petições para solicitar à Sereníssima a garantia de maiores e melhores condições de segurança para os comboios que ligavam Veneza a Split. Estes navios foram, nos primeiros tempos, escoltados por uma "galea commerciale", convenientemente armada e capaz de se defender de eventuais ataques dos piratas uscoques ou malteses. Mais tarde, em resultado dos pedidos insistentes de Daniel Rodriga, foram destinadas a estas viagens duas fuste $e^{104} \operatorname{armadas}^{105}$.

${ }^{102}$ Ibidem, Reg. 139, 22.10.1597. Veja-se, em apêndice, o documento n. ${ }^{\circ} 3$.

${ }^{103}$ Ibidem, 16.12.1596, onde os Sábios acenam com uma eventual recompensa para Daniel Rodriga e sustêm que esta não deverá ser cobrada em conjunto com as taxas recebidas pelo Estado, mas acordadas directamente entre ele e os mercadores interessados.

${ }^{104}$ A fusta (dialecto veneziano) era una galea de baixo bordo com 18-20 remadores de cada lado e um só mastro de vela latina. Cf. V. Guazzo, Enciclopedia degli Affari, Padova 1853, vol. VI, sub voce; Istituto Enciclopedia Italiana, Lessico Universale Italiano, Roma 1975, vol. VIII, sub voce. Conserva-se um modelo de uma fusta veneziana no Museu Correr, em Veneza.

${ }^{105}$ ASVe, CSM, Reg. 141, Prima serie, 23.7.1596 e 12.8.1596. 
O governo veneziano e os Cinco Sábios opuseram-se repetidamente à utilização destes navios para o transporte de mercadorias destinadas - ou provenientes de outros portos adriáticos e proibiram várias vezes o seu emprego «a Sud delle Bocche di Cattaro» ${ }^{106}$.

Em 1602, através de uma das suas últimas petições, Daniel Rodriga requereu à Sereníssima que favorecesse o resgate dos mercadores hebreus capturados pelos piratas e reduzidos à condição de escravos, não deixando de lamentar a falta de ajuda da parte do Governo de Veneza ${ }^{107}$.

No dia 15 de Setembro do mesmo ano, solicitou que a Nação Ponentina de Veneza não fosse obrigada a pagar o contributo para as despesas dos banchi de pegno.

\section{§ 6. De Bragança a Veneza: o Testamento de Daniel Rodriga}

Não obstante os diversos estudos que têm sido publicados sobre a notável obra empreendida por Daniel Rodriga, importa referir que não muita importância tem sido concedida à análise das origens deste famoso judeu sefardita. Por vezes, num ou noutro caso, os investigadores ainda acenam com expressões pouco precisas para identificar a nacionalidade de Daniel Rodriga, quando dizem tratar-se de um judeu de origem ibérica, de um judeu espanhol ou, então, levantino ${ }^{108}$. A própria forma como Daniel Rodriga se identifica, regra geral, na documentação existente (hebreu levantino ${ }^{109}$ ) contribuiu sobremaneira para que esta nuvem ensombrasse, quase até aos nossos dias, as verdadeiras origens do Cônsul da Nação Levantina e Ponentina de Veneza.

$\mathrm{O}$ facto de Daniel Rodriga figurar muito raramente nos documentos à guarda dos vários arquivos italianos e croatas como judeu português e de ter abandonado o país, em meados do século XVI, poderia porventura ser motivo para que se considerasse, embora de forma menos avisada, que as suas origens não marcaram profundamente, a vários níveis, a sua actuação no tempo do desterro.

${ }^{106}$ Veja-se, por exemplo, ASVe, CSM, Reg. 141, fls. 24-26, 12.08.1602, Capitoli per la navigazione di Spalato: foram destinadas à Navegação de Split duas fustas armadas (como foi requerido por Daniel Rodriga) e proíbe-se que estas possam dirigir-se aos portos "alieni", isto é, não pertencentes a Veneza.

${ }^{107}$ Ibidem, Reg. 149, fls. 90v-91r: 19.1.1599.

${ }^{108}$ Ficou a dever-se a P. C. Ioly ZorattinI, Processi, XIII, p. 19, a comprovação inequívoca das raízes lusitanas de Daniel Rodriga.

${ }^{109} \mathrm{O}$ Império Otomano - e o Levante - estendiam-se até à margem oriental do Adriático. Daniel Rodriga podia intitular-se como ‘levantino’, porquanto tinha vivido muito tempo ao longo dessa costa, em particular em Narenta. 
Conforme se procurou expor nas páginas anteriores, o estudo das muitas acções empreendidas, ao longo de várias décadas, pelo infatigável Daniel Rodriga, em prol dos seus correligionários, não pode ser realizado, sob pena de ser parcelar e incompleto, sem a assunção de que se trata, efectivamente, de um judeu português, natural da cidade de Bragança, na região de Trás-os-Montes, onde nasceu por volta de 1523.

Na verdade, Daniel Rodriga, à semelhança dos seus conterrâneos dispersos pelas várias comunidades judaico-portuguesas, carregava consigo uma cultura, uma religião, uma língua (a portuguesa ${ }^{110}$ ) e um passado comuns que faziam deles, necessariamente, um grupo com características próprias e distintivas em relação às restantes comunidades judaicas com que coexistiam. Daniel Rodriga é um homem que tem a perfeita noção desta realidade, quanto mais não seja porque a conhece e vive directamente no terreno, pelo que procura, em momentos e formas diferenciados, conservar e solidificar este património, colocando estas várias comunidades no caminho do desenvolvimento sustentado pelas principais rotas comerciais transadriáticas. A este título, são particularmente significativas as muitas diligências que o diplomata português nunca se cansou de fazer no sentido de apoiar e desenvolver os laços antigos que, desde há muito, uniam os membros das Nações Portuguesas dispersas ao longo das costas do Mediterrâneo, onde se destacam, evidentemente, as de Veneza, Narenta, Split, Ragusa, Durazzo ou Salonica.

Além disso, as múltiplas acções protagonizadas por Daniel Rodriga revelaram-se de enorme importância, não só para os seus conterrâneos já exilados, mas também para os muitos cristãos-novos que continuavam a abandonar Portugal, na segunda metade do século XVI. As denúncias enviadas por Frei Zacarias de Lisboa ${ }^{111}$ ao Santo Ofício de Roma constituem, a este respeito, a principal fonte conhecida para ilustrar os contactos frequentes que Daniel Rodriga mantinha com alguns familiares residentes em Lisboa, que aí se distinguiam como membros activos da

\footnotetext{
${ }^{110}$ Para uma perspectiva geral da questão linguística no que concerne aos judeus portugueses desterrados, nomeadamente do frequente bilinguismo português-castelhano nos textos literários, cf. A. M. L. Andrade, «Os Senhores do Desterro de Portugal...», op. cit., pp. 93-99.

${ }^{111}$ A documentação referente a este episódio encontra-se transcrita integralmente em P. C. IoLY Zorattini (ed.), Processi, XIII, pp. 179-208 (Fra’ZZaccaria Portoghese, 1594); 209-215 (Nuno da Costa, 1594); 217-225 (Padre Cristoforo, 1594). Para uma análise minuciosa da denúncia de Frei Zacarias de Lisboa, cf. P. C. Ioly Zorattini, «Un Profilo del Marranesimo alla fine del ‘500: la Denuncia al S. Uffizio Romano di Fra’ Zaccaria di Lisbona»: H. Méchoulan - G. NAHON (eds.), Mémorial I.-S. Révah. Études sur le marranisme, l'hétérodoxie juive et Spinoza, Paris-Louvain 2001, pp. 529-543. Ficou a dever-se ao mesmo Frei Zacarias de Lisboa, que viveu grande parte da sua vida em Itália, a tradução para italiano da obra Imagem da Vida Cristã de Frei Heitor Pinto (Imagine della Vita Christiana, In Venetia, presso Erasmo Viotti, 1594).
} 
comunidade judaica. De facto, o Cônsul desempenhava, segundo o testemunho escrito apresentado pelo referido frade capuchinho, um papel capital na rede de apoio aos cristãos-novos portugueses que pretendiam deixar o país natal rumo à península itálica.

No regresso de uma viagem a Portugal, Frei Zacarias de Lisboa foi encarregado pelo cardeal Giulio Antonio Santori de desenvolver algumas investigações sobre os judaizantes portugueses que habitavam em grande número por terras italianas. O frade capuchinho procede ao envio de várias cartas de Veneza para Roma, na segunda metade de 1594, dando conta de aí ter encontrado um mercador cristão-novo disposto a denunciar os seus inúmeros compatriotas que professavam a fé mosaica. Na impossibilidade de conduzir o denunciante a Roma para prestar declarações em pessoa, Frei Zacarias entregou ao tribunal romano, no dia 3 de Novembro de 1594, uma extensa relação dos judaizantes portugueses que viviam em Itália e noutras partes da Europa, sem excluir a própria Península Ibérica ${ }^{112}$. A listagem encontra-se redigida em língua portuguesa e italiana e integra um conjunto alargado de judeus portugueses, seriados segundo as localidades em que viviam à época.

Ora, é justamente Daniel Rodriga que encabeça este extenso rol, pois é a primeira figura a ser assinalada entre os cristãos-novos residentes no Ghetto de Veneza. O documento traça um retrato minucioso do judeu português com indicações precisas sobre a sua naturalidade, família e actividades:

Daniel Rodrigua, natural de Bragana de muitos annos a esta parte é vindo de Portugual a esta cidade onde está por consul dos Judeos por seu meio e a seu chamado se vêm aqui todos os Judeos portugueses dizendo que sam Levantinos e elle nesta Republica assi mesmo tem dado entender que é levantino e pollos serviços que faz a esta Republica em lhe fazer pera aqui vir tantos Judeos e por outros serviços lhe tem dados aqui de tença 200 cruzados. Não se sabe o nome que tinha em christão. Os Christãos Novos de Portugual que têm respondencia com elle lhe chamam lá o Capitão Rodrigua. Tem hum irmão que também se chama o Rodrigua, o qual está tambem por consul na scala de Spalato. O Daniel Rodrigua é aqui casado com huma sobrinha de Manoel Drago filha de huma sua irmãa. Sua molher chama-se de alcunha a Rodrigua à qual Manoel Draguo seu tio que em Lisboa mora à Conceição

${ }^{112}$ Esta relação foi entregue ao Santo Ofício de Roma em conjunto com algumas cartas e uma petição que havia sido dirigida a Frei Zacarias por Frei Crisóstomo da Visitação (P. C. Ioly Zorattini (ed.), Processi, XIII, 217-225 - Padre Cristoforo, 1594), na qual este cisterciense, igualmente português, reflecte sobre a melhor estratégia para julgar os judaizantes portugueses e espanhóis. Cf. P. C. Ioly Zorattini, «Un Profilo del Marranesimo...», op. cit., pp. 535, 540-542. 
manda a aqui dinheiro e se cartea com o Rodrigua seu marido. E alem disto se diz que tem tambem aqui alampada na sinagoga deste gueto. ${ }^{113}$

A partir desta importante denúncia, verifica-se que o Capitão Rodriga, como era conhecido o cônsul no seu país de origem, mantinha uma correspondência regular com membros da comunidade judaica de Portugal, em particular com um tio da mulher, chamado Manuel Drago. Um e outro são apontados como elementos destacados na rede de apoio aos cristãos-novos que continuavam a deixar Portugal com destino a terras italianas, como deixa entender, mais adiante, o texto referente ao próprio Manuel Drago:

Manoel Drago morador à Conceição, segundo delle dizem os Judeos, tem aqui alampada neste gueto e de Portugal tem respondencia com estes Judeos todos especialmente com Daniel Rodriga consul delles e hum e o outro sam os que aqui fazem vir todos quantos vêm de Portugal onde o Draguo comprou huma negra e a mandou a Ferrara a hum judeu que a fizesse judia. ${ }^{114}$

Comprova-se, por conseguinte, que o distanciamento de Daniel Rodriga em relação à sua terra natal não o impediu de continuar a manter laços estreitos com alguns compatriotas que aí permaneciam. Naturalmente, as funções de cônsul que desempenhou, em vários locais, como legítimo representante da respectiva comunidade, colocavam-no numa posição privilegiada para poder auxiliar, tanto os compatriotas que pretendiam abandonar Portugal, como aqueles que já o haviam feito e estavam dispersos pelos vários núcleos estabelecidos sobretudo nas costas do Adriático.

Daniel Rodriga e os seus compatriotas desterrados transportavam consigo, não apenas a simples lembrança da pátria que os vira nascer, mas também as marcas próprias que faziam deles, a um só tempo, judeus e portugueses. No final da vida, meio século volvido após a partida do Reino, Daniel Rodriga, em perfeito domínio do seu «juiso e entendimento», não obstante a grave enfermidade que o retinha no leito, mandou passar a escrito as suas últimas vontades. Para esse efeito, no dia 23 de Maio de 1603, mandou vir a sua casa, no Ghetto Vecchio de Veneza, o notário Giovanni Andrea Catti e o judeu Jehuda Alteras que lavrou o testamento ${ }^{115}$. Com pouco mais de oitenta anos,

${ }^{113}$ Cf. P. C. Ioly Zorattini (ed.), Processi, XIII, pp. 192-193.

${ }^{114}$ Cf. P. C. Ioly Zorattini (ed.), Processi, XIII, pp. 200-201.

${ }^{115}$ Assinala-se a publicação recente de um trabalho de M. ORFALI [ «Aspectos sociales y espirituales de los sefardíes de Ragusa a través de la documentación testamentaria (siglos XVI-XVII)»: Sefarad 66, n. 1 (2006), pp. 143-182] com o estudo de vários testamentos de judeus sefarditas estabelecidos em Dubrovnik, redigidos em latim e italiano. Entre os testadores dos seis documentos 
o diplomata português não conseguiu resistir à doença fatal que, decorridos apenas vinte dias, lhe havia de causar a morte. Desaparecia, assim, em 6 de Junho de 1603, uma das figuras mais prestigiadas da comunidade judaico-portuguesa de Veneza ${ }^{116}$.

O testamento referido, conservado à guarda do Archivio di Stato de Venezia, constitui uma prova irrefutável das origens lusitanas de Daniel Rodriga, porquanto se encontra redigido na sua língua materna, ou seja, em português. Conforme se consigna no documento, o testador ditou as últimas vontades, por sua expressa e livre vontade, a Jehuda Alteras e, depois de estas terem sido redigidas e lidas em voz alta pelo escrivão, confirmou-as, segundo era costume, perante o notário veneziano e várias testemunhas.

É bastante significativo assinalar, antes de mais, que o texto não foi escrito pelo próprio testador, mas pelo escrevente, um judeu português de quem se desconhece o nome de baptismo. Na verdade, Alteras/Altaras é o apelido de uma família portuguesa, cujos membros estão presentes em Ferrara, Ancona e Veneza desde meados de Quinhentos ${ }^{117}$. A participação de Jehuda Alteras no processo do testamento de Daniel Rodriga, a par do notário veneziano, não deve ser entendida como um mero acaso. A Nação Portuguesa, um pouco à semelhança do que sucedia no período anterior à expulsão de Portugal, possuía uma complexa organização interna, com uma alargada autonomia administrativa e jurisdicional (com a faculdade de impor e cobrar taxas), a que estavam vinculados todos os seus membros ${ }^{118}$. Não obstante a complexa organização e funcionamento das várias comunidades hebraicas de Veneza, estamos convictos de que Jehuda Alteras desempenhava as funções próprias de um escrivão oficial da Nação Ponentina, como comprova, desde logo, a sua intervenção no acto requerido por

transcritos na íntegra contam-se alguns judeus portugueses, de entre os quais se destaca o célebre humanista eborense Diogo Pires, alias Isaia Cohen.

${ }^{116} \mathrm{O}$ registo do falecimento indica: «Daniel Rodrighes de anni 80 in circa, de febre mese uno, Ghetto Vecchio» - ASVe, Provveditori alla Sanità, Necrologi, reg. 831, c. 2r (Serie Ebrei). Cf. P. C. Ioly Zorattini, «L'inventario dei beni di Daniel Rodriga a Venezia»: P. C. Ioly Zorattini - A. M. CAProni (eds.), Memor fui dierum antiquorum: studi in memoria di Luigi di Biasio, Udine 1995, pp. 135-143: 135.

${ }^{117}$ É bastante provável que Jehuda Alteras fosse parente do rabino Moisés Altaras, a quem se ficou a dever a tradução do hebraico ao castelhano do Libro del mantenimiento de la alma de Joseh Caro, publicado em Veneza, no ano de 5369 [i.e.1609].

${ }^{118}$ Sobre o papel desempenhado pelos representantes da Nação Portuguesa que agiam como verdadeiros notários públicos junto da comunidade, cf. A. di LeONE LeONI, «The Pronunciation of Hebrew in the Western Sephardic Settlements»: Sefarad 66, n. ${ }^{\circ}$ (2006), pp. 103-108. 
Daniel Rodriga ${ }^{119}$. Não se estranha, por isso, que Jehuda Altarras seja definido pelo testador na qualidade objectiva de «escrivão deste meu testamento» (fl. $3 \mathrm{v}$ ).

A redacção do testamento apenas em língua portuguesa teria sido, decerto, mais do que suficiente no seio da comunidade judaico-portuguesa, não fosse estar em causa a recuperação de alguns créditos do testador junto de órgãos oficiais do Governo da Senhoria. Foi seguramente para acautelar, no futuro, a boa cobrança destes créditos que houve necessidade de mandar oficializar o testamento por um notário veneziano, com a realização adicional da tradução certificada do documento para a língua italiana ${ }^{120}$.

Além disso, uma análise geral das últimas vontades de Daniel Rodriga deixa transparecer claramente que a sua situação financeira, à data em que ditou o testamento, não era muito desafogada. Os seus ambiciosos e sucessivos planos de criação e desenvolvimento de novas rotas comerciais favoreceram, simultaneamente, o comércio veneziano e português, porquanto os projectos do judeu brigantino comportavam quase sempre a participação activa da rede de comunidades judaico-portuguesas, dispersa pelas margens do Mediterrâneo. As viagens necessárias aos estudos preliminares e à preparação comportavam custos elevados, como se percebe pelo pedido de adiantamento de 10.000 ducados que Daniel Rodriga endereçou à Sereníssima, em Outubro de 1597, para financiar a prospecção de novas rotas comerciais para Durazzo e Salonica ${ }^{121}$. Já anteriormente devia ter aplicado uma boa parte dos seus capitais na criação da escala de Split, cuja abertura não o terá decerto enriquecido. Tudo leva a crer, pois, que a persistência de Daniel Rodriga na concretização dos projectos traçados, nomeadamente o da via marítima para Durazzo e Salonica, por envolver quase sempre custos fixos iniciais elevados e de retorno bastante incerto, fez com que ele arriscasse mesmo o endividamento pessoal.

\footnotetext{
${ }^{119}$ Em obra recentemente publicada, B. CripPa,A. Veronese, C. Vivante, (eds.), La Comunità Ebraica di Venezia e il suo Antico Cimitero, Ricerca a cura di Aldo Luzzatto, Milano 2000, Vol. I, pp. 109, 285 (com base em A. BERLINER, Luhot Avanim, Hebraïsche Grabschriften in Italien, Ester Teil, Frankfurt am Main 1881, n. 24) referem que Yehuda Altaras «era "scriba" e cantore di Sinagoga», tendo morrido, com 65 anos, em 1619. Compreende-se, agora, à luz da participação deste no testamento de Daniel Rodriga, o real significado destas palavras, ou seja, Jehuda Alteras desempenhava oficialmente a função de notário («scriba»), não de uma comunidade indeterminada («di Sinagoga»), mas da própria Nação Portuguesa.

${ }^{120}$ Assinala-se que a tradução do testamento para italiano, ainda que incompleta, encontra-se à guarda do Archivio di Stato di Venezia juntamente com o documento original redigido em português.

${ }^{121}$ ASVe, CSM, Reg. 139, 22.10.1597. Veja-se, em apêndice, o documento n. ${ }^{\circ} 3$.
} 
Na verdade, a ajuizar pelas vontades expressas no testamento, Daniel Rodriga não tinha quase nenhuma disponibilidade financeira, o que deve ter dificultado bastante a acção dos testamenteiros nomeados que, praticamente sem liquidez, se viram a braços com a necessidade imediata de pagar com urgência os encargos e as dívidas que oneravam vários dos bens transmitidos em herança ${ }^{122}$. Refira-se, a este propósito, que até alguns objectos pessoais, como as jóias e outras peças deixadas à esposa do testador, a sua principal herdeira, estavam empenhados por um valor aproximado de 400 ducados. Com efeito, cada uma das fontes de rédito tinha sido dada como garantia a alguém que emprestara dinheiro, pelo que os administradores da herança estavam obrigados a resgatar os documentos que titulavam os créditos, antes de poderem executar as restantes disposições do testamento.

Daniel Rodriga constitui a esposa e prima, Dona Benvinda de Castro, como a sua herdeira principal, mostrando grande reconhecimento pela muita dedicação que ela sempre lhe devotou ao longo do casamento, em particular na doença. Assim, à conta dos 3.000 ducados do dote da esposa ${ }^{123}$, atribui-lhe os direitos de arrendamento (hazacot) de três casas no Ghetto Vecchio, propriedade da família Minotto: a sua própria habitação, com o respectivo recheio (incluindo as jóias dadas em penhor), bem como as duas casas onde então viviam Isaque Nahamias e Joseph Ysrael.

Daniel Rodriga designa como testamenteiros Abension Françes, seu cunhado, e JacobAbenine, a quempede, «en recompensa do ben, amore amisade sempre eitido a todas suas cousas», que cumpram escrupulosamente as suas últimas vontades, começando, desde logo, por ordenar a venda dos direitos de subarrendamento de duas casas (quiçá o activo mais facilmente realizável) e à cobrança dos seus créditos junto de várias entidades, de molde a obter a liquidez necessária ao pagamento das dívidas:

1) venda dos direitos de subarrendamento (hazacot) das casas onde residem Jehuda Mutal, a cunhada Dona Rica, esposa do testamenteiro, e Daniel Alfarin, pelo valor total aproximado de 1.700 ducados;

${ }^{122}$ A difícil situação financeira de Daniel Rodriga confirma-se, de algum modo, pela modéstia do recheio da sua casa do Ghetto Vecchio, à luz do inventário requerido pelo seu testamenteiro, Jacob Abenine, lavrado também pelo notário Giovanni Andrea Catti, no dia 3 de Julho de 1603. Veja-se a transcrição do inventário feita por P. C. Ioly ZoRATtini, «L'inventario dei beni di Daniel Rodriga...», op. cit., pp. 135-143.

${ }^{123} \mathrm{O}$ dote inicial, por ocasião das núpcias do casal, era de apenas 1.000 ducados, mas Daniel Rodriga decidiu posteriormente, não obstante as suas dificuldades financeiras, acrescentar a este valor mais 2.000 ducados. Note-se que o dote, em caso de divórcio ou falecimento do marido, devia ser restituído à mulher e constituía um crédito privilegiado. 
2) cobrança de 1.800 ducados do Officio dei Procuratori del Sale, valor remanescente do prémio que fora concedido a Daniel Rodriga pelos serviços prestados ao Governo veneziano, com a criação da escala de Split, à razão de 200 ducados anuais por 9 anos.

3) cobrança de 200 ducados/ano concedidos pelos mercadores cordevaneros ao cônsul português como recompensa da isenção e redução de direitos aduaneiros;

4) cobrança da renda anual de 300 ducados da Comunidade Hebraica Ponentina e outros 300 da Levantina, como prémio dos benefícios alcançados «comforme a tarifa notada no officio dos senhores Sinco Sabios e en livro de cada cahal e cahal», relativamente às mercadorias provenientes do Levante.

Note-se que alguns destes direitos de crédito tinham sido dados em garantia de empréstimos, pelo que, na prática, não era possível dispor das respectivas quantias, sem primeiro amortizar as dívidas contraídas. A única forma possível de o conseguir era vender primeiro os referidos direitos de subarrendamento (hazacot). Deste modo, foi ordenado aos administradores da herança que, à medida que fossem cobrando os valores acima referidos (à volta de 3.700 ducados), procedessem ao pagamento, por esta ordem, das seguintes dívidas, orçadas em cerca de 1.400 ducados:

1) a Abension Françes, testamenteiro e cunhado de Daniel Rodriga, 300 ducados do dote da irmã que ainda estavam em falta (em penhor desta dívida estava o direito de subarrendamento das duas casetas, a da cunhada e a de Daniel Alfarin);

2) a Isaque Nahamias, 300 ducados (em penhor desta dívida encontrava-se o direito de subarrendamento da casa onde vivia o credor);

3) à esposa, a quantia necessária para desempenhar as jóias, valor avaliado em cerca de 400 ducados;

4) a Jehuda Mutal, 300 ducados que este adiantara a título de pagamento de rendas.

Depois da liquidação das dívidas supracitadas, Daniel Rodriga requereu aos administradores da herança que, recorrendo aos 2.300 ducados remanescentes, procedessem do seguinte modo em relação aos seus sobrinhos, a quem «por averen-me desonrado con suas mas artes e hobras», mandava que somente lhes fosse dado:

1) às sobrinhas, filhas do irmão Jacob Rodriga, o direito de subarrendamento das casas onde mora Jehuda Altarras, o escrivão do testamento, e das 
casas onde reside Raphael Habib. A concessão efectiva deste direito às herdeiras, livre de ónus e encargos, dependia, uma vez mais, da liquidação prévia, por parte dos administradores da herança, de duas dívidas contraídas pelo testador, uma de 350 ducados a Raphael Habib e outra de 106 ducados a Jacob Alfarin;

2) a Mose Rodriga, filho do irmão Isaque Rodriga, somente 10 ducados «por ser ele mao homẽi desonra da nosa jeração e por aver con ele gastado muito dinhero e ele ser cada vez pior». Sob condição de o sobrinho ir viver para Safed como «bom judeu», em expiação «de suas mas hobras» e obediência às ordens da tia, mulher de Daniel Rodriga, este ordena aos administradores da herança que lhe mandem 24 cequins/ano, por um período de vinte anos, «para ajuda de sua mantensa».

Após o pagamento integral de todas as dívidas e o cumprimento de todas as vontades anteriores, Daniel Rodriga ordena as suas disposições finais: que o montante remanescente seja entregue pelos apotroposut à mulher, para que esta «dee por minha alma ducados tresentos para ajuda do casamento de tres orfãs que lhe deixo hordẽi» e, além disso, pague os ofícios religiosos que têm lugar, segundo o costume hebraico, decorridos sete dias, um mês e um ano após o funeral.

Procede-se, de seguida, a uma breve análise linguística do testamento lavrado em língua portuguesa, de molde a definir e caracterizar os seus traços fundamentais ${ }^{124}$.

Em primeiro lugar, deve acentuar-se que o texto está marcado pela existência, facilmente compreensível, de vários vocábulos e expressões oriundos da língua italiana, entre as quais destacamos familha (fl. 1r), çervitu (fl. 1r), fito (fl. 1v), simelmente (fl. 2r), creditore (fl.2r), dassio (fl. 2.r), cauttion (fl. 2r), finir do tempo (fl. 2r), le (m) presentare (fl. 2v), pur (fl. 3r), huna volta sola (fl. 3r), ciquinos (fl. $3 \mathrm{r}$ ), verso (fl. $3 \mathrm{v})$, maggestrato (fl. $3 \mathrm{v})$. Em menor número, encontram-se também vestígios do castelhano em formas como tan solamente (fl. 2v) ou erensa (fl. 3r).

\footnotetext{
${ }^{124}$ Para uma análise global da evolução da língua portuguesa escrita, em particular da chamada fase moderna (da segunda metade do século XVI ao final do século XVIII), cf. Evanildo BECHARA, «As fases da língua portuguesa escrita»: D. Kremer (ed.), Actes du XVIII ${ }^{e}$ Congrès International de Linguistique et de Philologie Romanes, Tome III, Tübingen 1991, pp.68-76.
} 
Convém referir igualmente que o testamento está permeado por algumas palavras e expressões comuns na linguagem judaico-hispânica, sobretudo de origem hebraica e grega, como apotroposim (fl. 1r), quetuba (fl. 1r), haham/ hahamim (fl. 1v), hazaca/hazacot (fl. 1v), cahal cados talmud tora (fl. 1v), cahal e cahal (fl. 2r), apotroposut (fl. 3v), capara (fl. 3r).

Por outra parte, o texto em análise apresenta duas marcas linguísticas que indiciam que o escrevente era, com grande probabilidade, originário da região centro-sul de Portugal. Referimo-nos, em concreto, tanto à confusão generalizada, ao longo do documento, no registo das sibilantes, como à monotongação frequente dos ditongos $<\mathrm{ou}>\mathrm{e}<\mathrm{ei}>$, atestada em formas como primeramente (fl. 1r), oro (fl. 1r), dinhero (fl. 1r), primero (fl. 1v), ovesẽi (fl. 1v), poco (fl. 2v), over (fl. 3r), overẽi (fl. 3v). A oscilação gráfica no registo das sibilantes, evidenciada ao longo de todo o documento, parece ser uma consequência do processo de simplificação do antigo sistema de quatro sibilantes, ocorrido no século XVI, cujo resultado, na região centro e sul do país, se reduziu, de forma inovadora, ao uso do par de fricativas predorso-dentais [s] e [z]. A título de exemplo das frequentes hesitações presentes no documento, indicam-se as formas obçervar, çirvidor, çerviso (fl. 1r), merse, pesso (fl. 1v), dusentos, çirviço, çinco, sinco (fl. 2r), des (fl. 2v), tresentos, fassa, fassão, fasão, asima, comeso (fl. 3v), trese (fl. 4r).

Merece-nos um comentário particular a forma como está grafada a vogal nasal [ẽ], em sílaba final. As grafias <ẽ >, <en > e <em > são as esperadas, no século XVI, para esta vogal nasal. $\mathrm{O}$ texto em análise, porém, apresenta para a mesma vogal duas grafias distintas $-<$ eim $>$ e $<$ ẽi $>-$, que denunciam desde logo a sua ditongação, bem marcada graficamente, o que revela também uma certa proximidade da oralidade. Acrescenta-se que a grafia <ẽi> é a mais usada pelo escrevente (exceptuam-se as palavras ordeis, fl. 1v; ordeim, teim, fl. $2 \mathrm{r}$; teim, fl. 2v; quiseseim, beim, tambeim, fl. $3 \mathrm{v}$ ), pelo que foi a adoptada na transcrição em todas as ocorrências.

São visíveis no texto alguns fenómenos de harmonização vocálica, quer do timbre da vogal da sílaba pré-tónica em relação ao da sílaba tónica (siguinti, fl. 1v; çirviço, fl. 2r; gintil, fl. 3r), quer do timbre da vogal da sílaba átona em relação ao da sílaba átona seguinte (brividade, siguirão, fl. 1v; hobidiensia, fl. 3r).

Assinala-se, por último, no caso dos grupos consonânticos $\langle\mathrm{cl}\rangle \mathrm{e}<\mathrm{bl}\rangle$, que está atestada no texto a conservação parcial do grupo consonântico, com a transformação da lateral em vibrante. Este processo verifica-se, por exemplo, em formas como decrarar, decrararei (fl. 1r), pubrico, decraro (fl. 1v).

Nos critérios de fixação do texto, adoptámos, fundamentalmente, as normas apresentadas por Avelino de Jesus da Costa, Normas gerais de transcrição e 
publicação de documentos e textos medievais e modernos, Coimbra ${ }^{3} 1993$. Deste modo, procedemos ao desdobramento de abreviaturas, à actualização do uso de maiúsculas e minúsculas, à introdução da pontuação indispensável, bem como à separação das palavras que se encontravam unidas e à junção de sílabas ou letras da mesma palavra que, no texto, estavam separadas. Refira-se, a este propósito, o caso dos advérbios de modo terminados em -mente, cujas duas partes constituintes aparecem quase sempre (exceptuando somente, fl. 3r) separadas no documento (e.g. primeramente, maximamente, fl. 1r; juntamente, fl. 1v; simelmente, liquedamente, fl. $2 \mathrm{r}$; solamente, fl. 2v; lealmente, fl. $3 \mathrm{r}$ ). As letras ou palavras entrelinhadas colocam-se entre $<>$; as lacunas do texto e reconstituições de letras ou palavras que faltam no original põem-se entre parêntesis rectos; as indicações de nossa autoria encontram-se entre parêntesis curvos.

\section{Apêndice DOCUMENTAL}

\section{Documento N.0 1}

\section{Veneza, 23.3.1603 - Testamento de Daniel Rodriga}

Fonte: ASVe, Notarile Testamenti, B. 347, not. G. A. Catti, Testamento 159

Testamentum Danielis Rodrighes haebrei mihi Jo[hannis] Andreas de Cattis Venetiarum notario praesentatum sub die xxiii Maii 1603 in praesentia testium ut intus. ${ }^{125}$

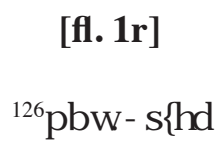

Sendo toda pesoa hobrigada a dar conta de si a hora de sua morte, ou antes por milhor poder decrarar suas cousas, achando-me eu Daniel Rodriga indesposto na minha cama deitado doente, empero al Dio graçias en todo meu juiso e entendimento, da minha espontania e intera vontade sẽi ninhuma força,

${ }^{125}$ Testamento do judeu Daniel Rodriga, que me foi apresentado a mim, Giovanni Andrea Catti, notário de Veneza, no dia 23 de Maio de 1603, na presença das testemunhas de acordo com o que se segue.

${ }^{126} \mathrm{~A}$ abrir o testamento encontra-se o símbolo hebraico _Qf $\square$ bj V\$ que significa 'Com a Ajuda de Deus'. 
decrararei neste meu testamento a minha ultima vontade e entenção, da qual mando se fação duas copias, huma nesta lingua portugueza, e outra en lingua italiana, qual sera comprido sendo el Dio Bemdito çervido levar-me para si, suplicando a meu principe ma fasa ajudar e con justiçia obçervar quanto nela decrararei, como leal e fiel çirvidor que sempre lhe ei sido, rogando al Dio me ajude sempre a fazer minhas cousas a seu santo çerviso amen.

Primeramente mando que todo este meu caserio altibaxo, comesando destas casas onde ao presente eu moro con minha familha e as casas dariba donde ao pre[se]nte mora o senhor Isaque Nahamias e as casas dabaxo onde ao pre[se]nte mora Rabi Joseph Ysrael jenro de David Cohen de Tripol, e o banho que esta a par delas, todas estas tres moradas de casas e ho banho con todo o mobel e peças e joias de prata e oro que se achar das minhas portas adentro, e asi joias e peças outras tenho empenhado fora de casa en poder de senhores quais minha mulher e prima senhora Dona Benvenida sabe, tudo quero e mando seja da dita senhora minha mulher e prima apoticado, a conta dos tres mil ducados pertende de mi aver por sua quetuba ${ }^{127}$, convẽi a saber ducados mil que lhe fiz quando logo con ela casei, e ducados dois mil que lhe cresentei pola boa companhia e gran çervitu ${ }^{128}$ me ha feito e çervido despois que con ela casei ate este dia, maximamente nas minhas doenças, que sempre me tẽi governado e procurado por mi e çervido-me não como mulher mas como escrava comprada por dinhero, pelo que quero e mando que os ducados 300 que dito senhor Isaque Nahamias pertende aver sobelas casas onde ele mora, e asi todo o dinhero lhe fizer de mister para desempenhar ditas joias, tudo mando lho ajão de desembolsar os meus apotroposim ${ }^{129}$ quais serão os que aqui decrararei, do milhor parado da minha fazenda // [fl. 1v] qual fazenda aqui decrararei, para que ela possa desembaraçar as casas do dito senhor Nahamias e desempenhar suas joias de poder de quẽi as tẽi, porque minha entenção he que tudo isso lhe fique liquido, limpo e desembaraçado pelos seus ducados 3000 da sua quetuba, como parese pelo cresentamento de dotta ${ }^{130}$ lhe tenho acresentado a ditta senhora minha mulher

${ }^{127}$ A palavra 'quetuba' [do hebraico $\mathrm{f} S \square \mathrm{V}=$ escritura, contrato nupcial] adquire, em sentido metafórico, o significado de 'dote'.

${ }^{128}$ Esta forma [do italiano 'servitù' = servidão] está usada, neste caso, em sentido hiperbólico, para sublinhar o extremo cuidado que a esposa de Daniel Rodriga sempre lhe dedicou ao longo da vida.

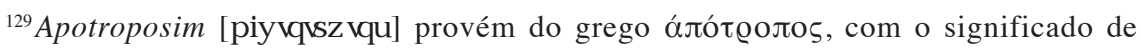
'administradores' ou 'executores testamentários'.

${ }^{130}$ É provável que o uso da forma dotta resulte da influência do italiano, onde a palavra 'dote' pertence ao género feminino, à semelhança do étimo latino. Segundo José Pedro MACHADO, Dicionário etimológico da língua portuguesa, s. u. 'dote', a adopção do género masculino em 
nas costas da sua quetuba, qual seja sempre valiosa diante toda justiça e trabunal como se feito fose con todas hordeis dos nosos hahamim ${ }^{131}$, e por mão de notario pubrico de Venettia con todas suas ordeis e clauzulas a ela pertençentes.

Decraro que achegando o tempo do pagamento dos ducados 300 de dito senhor Isaque Nahamias e os meus apotroposim lhe não ovesẽi pago seus ducados 300 , en tal caso quero e mando que dita senhora minha mulher lhos page das mesmas casas onde mora dito senhor Nahamias, e não possa delas tira-lo ate lhe pagar por intero todos os seus ducados 300, os quais ducados 300 ficara sempre ela a cobrar dos meus apotroposim do primero dinhero meu lhes vier a mão, como assi tambẽi decraro na fin de dito cresentamento de dotta.

Meus apotroposim serão o senhor haham ${ }^{132}$ Rabi Abension Françes meu cunhado e o senhor Jacob Abenhine a quais juntamente por merse pesso aceitẽi este tal cargo en recompensa do ben, amor e amisade sempre ei tido a todas suas cousas, quais ambos senhores apotroposim siguirão en tudo e por tudo, sobre todo o que meu se achar, minha hordẽi que he ho siguinti:

Primeramente mando que con a brividade posible vejão ditos senhores meus dois apotroposim vender as duas minhas hazacot ${ }^{133}$ que são as casas honde hao presente mora o senhor Jehuda Mutal qual dado me tẽi ducados tresentos agalder $^{134}$ e tẽi pago o fito ${ }^{135}$ ate 23 Abril proximo pasado 1603 a resão de ducados 40 ao ano, e a outra hazaca ${ }^{136}$ he as duas casetas que são honde ao presente mora minha cunhada Dona Rica, mulher do senhor haham apotropos meu cunhado, numa delas, e nas outras mora agora Rabi Daniel Alfarin, quais casetas tẽi dito haham meu cunhado en penhor por ducados tresentos lhe fiquei devendo por resto da quetuba de dita minha cunhada como parese por hum escrito meu que tẽi dito haham meu cunhado// [fl.2r] cunhado de ditos ducados 300 , e fasão de ditas duas hazacott dinheiro de contado para dele siguirei minha hordẽi como decrararei.

português, ter-se-á ficado a dever à analogia com outros nomes em -ote e à influência do francês 'dot', masculino nos séculos XVI e XVII, de onde o vocábulo terá tido a sua origem.

${ }^{131}$ Hahamim [do hebraico _XVZ= sábios, rabinos], plural de haham.

${ }^{132}$ Vide, supra, nota 133.

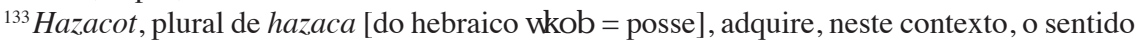
de 'direito adquirido de habitar uma casa'. Hazaqah

${ }^{134} \mathrm{~A}$ forma 'agalder' parece resultar de um erro de transcrição da palavra 'aluguer', conforme é sugerido pelo contexto.

${ }^{135}$ Do italiano 'affito' com o significado de 'renda'.

${ }^{136}$ Vide, supra, nota 135. 
Simelmente ${ }^{137}$ farão e procurarão ditos senhores apotroposim de cobrar ducados mil hoitoçentos que eu vou [constituir-me] creditor ${ }^{138}$ no illustrissimo Officio del Sal ${ }^{139}$ a ducados dusentos cada hano por hanos nove, que são por resto dos ducados quatro mil ei avido da sua Serenità ${ }^{140}$ para sustentasão da minha familia, a qual familia decraro seja dita senhora minha mulher e outras moças e viuvas a quẽi ela restara hobrigada a dar o que eu lhes deixar por minha alma como abaxo decrararei.

Simelmente cobrarão ditos apotroposim por hun scrito dos mercadores cordevaneros quais me dão cada hano ducados dusentos enquanto ho principe não tornar o dassio ${ }^{141}$ ho scrito ho tẽi os erdeiros de Joseph Gaon por cauttion ${ }^{142}$ e penhor de ducados dusentos lhes devo pagar aos 15 de Maio presente quais me empresto dito Joseph Gaon e mando se lhe pagẽi a ditos seus erdeiros, e tomẽi deles dito scrito, qual scrito he a chi presentara. E estimeno muito por que ho prinçipe não tornara mai aquel dassio, por que ho recordo foi bom, e eu pago ducados 20 cada hano de <da $>$ huma mulher como sabe Jacob Abenhine os quais se contẽi naqueles ducados 200 de modo que a ditos meus apotroposim fica cobrar cada hano de ditos cordevaneros liquedamente ducados 180 porque os ducados 20 vão a dita mulher, e agora que fazẽi os cordevaneros scola ${ }^{143}$ determinarão quẽi os a-de pagar, que ate agora os pagarão Raspi e Franqueti, e cada cinco anos quando se acabão os que corrẽi se vai aos illustrissimos senhores Sinco Sabios e se lhes recorda o finir ${ }^{144}$ do tempo i eles mesmos por çirviço pubrico vão en colejo e fazẽi meter parte de outros sinco anos.

${ }^{137}$ Do italiano 'simelmente'.

${ }^{138}$ Do italiano 'creditore'.

${ }^{139}$ Trata-se de uma referência a uma repartição alfandegária veneziana que era conhecida como Officio dei Procuratori del Sale.

${ }^{140}$ Governo veneziano.

${ }^{141}$ Dassio [do italiano 'dazio' = imposto, taxa, direito] aqui usado com o sentido específico de direitos aduaneiros. A interpretação deste passo é, por isso, a seguinte: 'enquanto o príncipe não voltar a instituir novamente os direitos de que Daniel Rodriga tinha conseguido obter uma isenção'.

${ }^{142}$ Do italiano 'cauzione'.

${ }^{143}$ A expressão 'fazer [e]scola' está aqui usada no sentido de 'reunir-se'. O nome hebraico da Sinagoga é Bet-Kenesset [ $\square \mathrm{hR}(\mathbb{\square}$ ] , que significa, literalmente, 'casa de reunião', razão pela qual 'fazer escola' passou a significar, em sentido metafórico, 'reunir-se'. A palavra 'scola', aliás, fazia parte do dialecto judaico-hispânico usado pelos judeus portugueses em Itália.

${ }^{144}$ Da expressão italiana 'finire del tempo', que aqui indica o término do quinquénio durante o qual haviam sido concedidas as isenções aduaneiras. 
Simelmente cobrarão ditos apotroposim do cahal cados talmud tora ${ }^{145}$ ducados tresentos, e de cahal cados levantinos outros ducados tresentos, quais hums e outros são por conto das mercaderias que venẽi de Levante comforme a tarifa notada no officio dos senhores Sinco Sabios e en livro de cada cahal e cahal ${ }^{146}$ como tudo mui bẽi sabe e vai cobrando dito senhor Jacob Benhin meu apotropos.

Decraro que vendido que avrão ditos meus apotroposim a hazaca onde esta dito senhor Jehuda Mutal por poco mais o menos dos ducados noveçentos por ela me davão, e assi a hazaca das casetas por poco mais o menos dos ducados oitocentos por ela achava // [ff.2v] e cobrando do Officio do Sal os ducados 1800 e dos cordevaneros os ducados 200 cada ano que en tudo monta ducados 3700 poco mais o menos, quero e mando que assi como forẽi cobrando os dinheiros todos ou parte vão con eles pagando as minhas dividas quais são algumas que aqui decrararei e outras que tenho dado en notta a ditta senhora minha mulher.

Primeramente quero que o haham meu cunhado apotropos s'embolse desta minha fazenda arriba decrararada, dos seus ducados 300 lhe devo sobre dittas casinhas de que tẽi hum scrito meu qual rompera e ficara pago por inteiro de toda suma da quetuba de sua mulher Dona Rica minha cunhada ultra otros ducados 20 me deve de fora via quais lem presento $^{147}$.

Dispois darão ditos meus apotroposim a dita senhora minha mulher os ducados 300 fica devidora ao senhor Isaque Nahamias sobre as casas onde dito Nahamias mora, para que ela lhos page e saia da sua obrigação e desembarase suas casas.

Simelmente lhe darão mais ditos apotroposim a dita senhora minha mulher todo o dinhero lhe sera neçesario para desempenhar suas joias como ditto temos.

Dispois pagarão ao senhor Jehuda Mutal os seus ducados 300 lhe devo que mos tẽi dado <de $>$ agalder sobre ditas casas onde ele mora.

Decraro que pagado que averão ditos meus apotroposim estas minhas dividas arriba decraeadas que todas poderão emportar da ducados 1300 ou 1400 poco mais ou menos, tirando estes dos ducados 3700 poco mais ou menos, ainda ficão en poder de ditos meus dois apotroposim da ducados 2300 in sirca dos quais farão o que dispois decrararei.

\footnotetext{
${ }^{145}$ Santa Comunidade Talmud Tora (Estudo da Tora, Lei). Era este o nome da Comunidade Hebraica Portuguesa, quando se referia a Veneza.

${ }^{146}$ De ambas as Comunidades (Ponentina e Levantina).

${ }^{147}$ Do italiano 'le presentare', com o sentido de 'Ihe ofereço'. A forma 'lem', tal como se lê no documento, parece resultar de um erro de redacção, em vez de 'le'.
} 
Quanto ao que toca as minhas erdeiras filhas de meu irmão Jacob Rodriga €]Xe assi a meu erdeiro Mose Rodriga filho de meu irmão Isaque Rodriga €]X quero e assi mando a ditos meus apotroposim que por averen-me desonrado con suas mas artes e hobras lhes seja dado tan solamente ${ }^{148}$ aquilo que aqui decrarar a saber:

As filhas de dito meu irmão Jacob Rodriga por resto e saldo de toda esta sua erensa ${ }^{149}$ lhes deixo as casas onde ao presente mora Jehuda Altarras escrivão deste meu testamento, e as outras casas dabaxo onde mora o senhor Raphael Habib €]Xlivres dos ducados 350 se devei a dito senhor Habib por hun instrumento, e tambẽi de outros ducados 106 que devo // [fl.3r] que devo a Jacob Alfarin, os quais me fica devendo Rabi Samuel Cohen Salos, de modo que ditos meus apotroposim desembolsarão dos ditos ducados 2300 in çirca que me ficão como atras dito tenho ducados 456 a ditos dois senhores para que sejão ditas duas casas livres para as ditas erdeiras de Jacob Rodriga, dando ele antes dois scritos meus, a saber sua mai ${ }^{150} \operatorname{Dona~Lietta~}^{151}$ (?) Luna hun de ducados 300 quais juro pela hora en que me acho lhos não devo e pur ${ }^{152}$ lhos quero dar sẽi lhos dever, e outro çimel scrito meu que esta em poder de dito Jacob Alfarin de ducados 106 quais escritos dando-se em poder dos senhores meus apotroposim eles desembolsarão os ducados 456 por não pagarẽi ditas casas outro que ducados des cada hano ao gintil homẽi Minoto ${ }^{153}$ patrão do fundo salvo se ao diante over novidade nos pagamentos que agora se pagão quais casos decraro paga cada huma delas de fito ao presente ducados cinquenta cinco cada ano. E não se lhe dando a ditos meus apotroposim ditos dois scritos e lhe casarẽi lealmente o instrumento que tẽi dito Raphael Cabib sobre mi dos ducados 350, ditos meus apotroposim não sejão sotopostos desembolsar ditos ducados 456 outro que ducados des por huna volta sola ${ }^{154}$, quais lhes ficarão por resto e saldo de todo o que pertender podião de mi por parte de herensa, mas dando-lhes dita Dona Luna o scrito que tẽi en seu poder e Jacob Alfarin o

\footnotetext{
${ }^{148}$ Do castelhano 'tan solamente'.

${ }^{149}$ Sobre as várias hipóteses formuladas acerca da origem e evolução dos vocábulos 'herencia'/'herança' nas línguas castelhana e portuguesa, cf. José Pedro MACHADO, Dicionário etimológico da língua portuguesa, s. u. 'herança', e Joan Corominas, Diccionario crítico de la lengua castellana, s. u. 'herencia'.

${ }^{150}$ Note-se o registo da antiga forma da palavra sem ditongo nasal, ou seja, ainda com ditongo oral.

${ }^{151}$ Lê-se no documento simplesmente Ltta, que parece ser uma abreviatura do nome hebraico Lietta=Simha [f Z`Q].

${ }^{152}$ Do italiano 'pur(e)'.

${ }^{153}$ A família Minotto era proprietária de casas no Ghetto Vecchio.

${ }^{154}$ Do italiano 'una volta sola'.
} 
outro que tẽi en seu poder para que elles os ropão e casẽi dito instrumento ahora in termino de 6 meses ditos meus apotroposim sejão obrigados a comprir-lhes quanto dito tenho. Isto he o que mando as erdeiras de Jacob Rodriga.

Quanto a Mose Rodriga filho de meu irmão Isaque Rodriga deixo ducados des somente por resto e saldo desta sua erensa e isto por ser ele mao homẽi desonra da nosa jeração e por aver con ele gastado muito dinhero e ele ser cada vez pior, mas en caso que se for a Safette ${ }^{155}$ e la viver de bom judeu e fizer capara $^{156}$ de suas mas hobras e la estiver a hobidiensia do que lhe mandar sua tia minha mulher dita en tal caso mando a ditos meus dois apotroposim lhe mandẽi cada hano ciquinos ${ }^{157}$ vinte quatro para ajuda de sua mantensa, e isto por tempo de anos vinti e outra cousa mando lhe não dẽi por ninhum verso ${ }^{158}$. //

[fl. 3v] Mais decraro e mando e assi quero e he minha ultima vontade que despois que ditos senhores meus apotroposim overẽi paguo as dividas que aqui tenho decrarado que são do senhor haim meu cunhado ducados tresentos ducados 300 a senhora minha mulher para pagar ao senhor Isaque Namias ducados 300 mais a dita senhora para desempenhar suas joias ducados 400 poco mais o menos e a Jehuda Mutal ducados 300 ao senhor Raphael Cabib ducados tresentos cinquenta ducados 350 , a Jacob Alfarin ducados cento e seis ducados 106 , que en tudo monta ducados 1756 in çirca, e asi tambẽi dispois que ouverẽi pago as dividas que tenho dado en nota a ditta senhora minha mulher quero que todo o mais que sobejar poco o muito seja dado e entregado a ditta senhora minha mulher, desde agora de mais ultra os ducados tres mil da sua quetuba e cresentamento como dito tenho, para que ela daquela demasia dee por minha alma ducados tresentos para ajuda do casamento de tres orfãs que lhe deixo hordẽi e page as promesas dos meus tres comprimentos dos sete dias, mes e hano, e al Dio Bemdito encomendo minha alma, fassa dela o que for sua santa vontade. E a todos pesso perdão e ha meus amigos rogando fassão comigo e con minha casa como eu ei feito con todos eles metendo sempre minha pessoa e fazenda por eles. E o piadoso perdoe o pecado ${ }^{159}$.

Decraro mais que refudando algum dos dois meus apotroposim ditos dito apotroposut $^{160}$ o que ho não quisesẽi aceitar o que <não posa $>$ en tal caso quero que ho apotropos que ficar e aceitar dito apotroposut con o parecer e consintimento de dita senhora minha mulher fasão outro apotropos a quẽi a eles

\footnotetext{
${ }^{155}$ Cidade de Safed, na Galileia.

${ }^{156}$ Capara [do hebraico fV V significa 'expiação', 'penitência, 'arrependimento'.

${ }^{157}$ Ciquinos [do italiano 'zecchini'], antiga moeda de ouro da República de Veneza.

${ }^{158}$ Do italiano 'verso' com o sentido de 'meio', 'maneira'.

${ }^{159}$ Cf. Psal. 78, 38 .

${ }^{160} \mathrm{O}$ encargo de administrador da herança.
} 
dois bẽi pareçer, en lugar do apotropos que refudou como asima; quais meus apotroposim estes dois nomeados ou qualquer outro que se fizer como dito temos tenhão otoridade abastante da poder vender e recadar suas fazendas, mobeles e estabeles tanto da illustrissima Senhoria ${ }^{161}$ como de particulares e de poder compareser en todo e qual se qual sequer officio, maggestrato ${ }^{162}$ e trabunal e poder fazer otro comeso e $[\mathrm{m}] \mathrm{seu}<$ lugar $>$ que se posa solicitar e negosiar todo o que ocorrer as cosas de ditto supotroposut ${ }^{163}$ en general e en particular tanto quanto minha propria pessoa, o que esta entrelinha que não posa e tambẽi en seu lugar tudo reto e fermo. E por tudo isto assi ser minha ultima vontade // [fl. 4r] rogei a Jehuda Altarras me fizese este testamento na mesma forma arriba scrita e rogo as testimunhas a firmẽi. En Venettia a dia de Vernes trese do mes de sivan digo trese dias do mes de sivan 5363 de la criasion del mundo que são 23 Maio 1663, digo 1603. En Venettia e tudo recto e fermo.

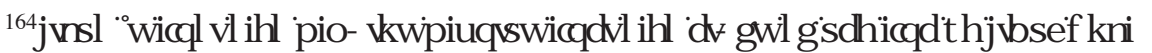

Jo Moise Alatino fisi[co?] fui presente a quanto sopra si contiene.

Eu Mordochai Calho fui prezente a quanto atras.

[Anno] Millesimo sexcentesimo tertio, die vero vigesimo terzio mensis Maij Indictione prima reperti in domo habitationis infrascripti testatarii in ghetto veteri Messer Daniel Rodrighes ha presentato à me Gio[van] Andrea Catti nodaro di Venetia il presente suo testamento fatto scriver come lui disse di manu di messer Giuda Alteras hebreo in lingua spagnola (sic) il quale [ho] visto havendoglielo io fatto legger alla mia presentia dal medesimo Alteras e esso Messer Daniel lo ha confermato et conferma e disse essere così la sua voluntà come in esso si contiene pregandomi che occorrendo la sua morte lo vogli far tradurre in lingua italiana et redurlo in forma pubblica con li addizioni ordinarie secondo l'uso di questa citta. Interrogato da me se vuol far scrivere altra cedula iusta la legge delli lochi (...) della città ha risposto non voler dire altro (...) praeterea.

${ }^{161}$ Parece ser o Senado de Veneza.

${ }^{162}$ Do italiano 'magestrato'.

${ }^{163}$ Deve ler-se apotroposut.

${ }^{164}$ Tradução: «Na minha presença passou-se tudo aquilo que está escrito acima e na presença dos doutores que assinam acima e diante do Senhor segundo [a Sua] vontade. Isac Garson testemunha». 
(Seguem-se as assinaturas de duas testemunhas)

Io Giacomo Biassio (sic) f[ili]o de messer Piero fui testimonio giurato et pregato alla sopraditta presentazione.

Io Antonio (?) Rimondi filio de messer Vit[ori]o fui testimonio giuratto et pregato ala ditta presentazione.

\section{Documento N.0 2}

\section{Dubrovnik, 05.05.1583 - Petição de Daniel Rodriga, em conjunto com} Samuel Ergas e Salamon Oef, dirigida às autoridades da República de Ragusa para concessão de facilidades aduaneiras.

Fonte: AHD, Acta Consilium Rogatorum, 3/67, fls. 125-127

\section{[fl. 125r] Die V Maii 1583}

Prima pars est de acceptando suplicationem Danielis Rodrighae, Samuelis Ergas [f. 125v] et Salamonis Oef hebreorum lectam in presenti Consilio pro 27 contra 12.

Seetnda pars est de non aeeeptando. (Cancelado após aprovação da primeira proposta).

Illustrissimi Signori, sendo io Daniele Rodriga in Narente sono venuto un giorno in ragionamento coll' Giovanni di Gondola al presente venditor del sale per le Signorie vostre Illustrissime in materia delle scale, et havendoli io detto che mi bastava l'animo sendo favorito dalle Signorie vostre Illustrissime co' le cose honeste di redurre il magior corso di quella scala in questa di Ragusa cosi co' li mercanti hebrei, et altre nationi forestieri, che volontariamente si servono dell'opera mia, et mi pregò ch'io facessi tal buona opera, et venissi a parlare co' le Signorie vostre Illustrissime perché lui era certo che io saria aiutato, et molto ben riconosciuto ${ }^{165}$ per il che sono alli piedi delle Signorie vostre Illustrissime insieme co' li consoli comoranti al presente in questa città, che sono Samuel Ergas, et Salamon Oef, et suplichiamo [fl. 126r] che a noi et non ad altri hebrei, ne sia concesso per anni cinque correndo il tempo in pace, come hora corre, et che tutte le robbe, che passarano per questa città tanto di levante, come di ponente riservando li suditi delle Signorie vostre Illustrissime che non paghino più di quello e dichiarito hora per la tariffa che si apresenta qui sotto, perché

${ }^{165}$ Segue-se uma palavra ilegível sob uma mancha. 
noi ne oblighiamo, che per il manco venirà per il transito all'ano più di scudi mille cinquecento, e non venendo fino la detta somma, io Daniele predetto con li detti consoli ne oblighiamo in solidum et a miglior tenente a rifarlo del nostro proprio, et perché sono certo che la sua molta prudentia potrà considerare il grand' utile che venirà di questa mia suplica al suo populo et datij, non dirò altro, che suplicare per la breve espeditione, e non voglio mancar dirle, che la mia opinione e, che facino quanto per la tariffa nell' altra mia suplica ${ }^{166}$, havevo presentato che era di ducati due corenti, perché sarebbe più fermamente fatta la [fl. 126v] scala, che non con questa di ducadi come hora facio et Il Dio ogni felicità al suo stato conceda.

Tariffa di quello [che] si ha da pagare delle robbe che andaranno et veniranno per transito per questa città di che banda esser si voglia.

- Per ogni somma di seta di levante ducati quattro che sono grossi ragusei 36 per ducato D 4;

- per ogni somma di giambelotti et mocairi ducati dui simili D 2;

- per ogni somma di spetie di ogni sorte indico et grana e simili D 1;

- per ogni somma di feltri tapeti et simili D 1;

- per ogni somma di cera grossi ragusei 18 18 ;

- per ogni sorte di cordovani per somma grossi 18 18 ;

- per ogni somma di montoni cori et boldroni et simili D 9;

- per ogni somma di lana o gotone D 18 ;

- per ogni migliaro di piombo terra ghleta or pi $[\mathrm{g}] \mathrm{menti}$ et simili D 9;

Delle robbe che andaranno in levante

- per ogni balla di panni cosi di Venezia come d'Ancona D 1;

- per ogni cassa di drappi di seta D 4 D 4;

[fl. 127r] - per ogni collo di carmese ducati dui D 2;

- per ogni cassa o collo di merci zucaro e simili D 9;

- per ogni migliaro di sapone e lini D 9;

Et havendo altre mercantie straordinarie, che qui non sono nominate si meterà a ragione $\mathrm{di}=$ per cento.

${ }^{166}$ Documento não localizado. 


\section{Documento N. ${ }^{\circ} 3$}

\section{Veneza, 22.10.1597 - Pedido de Daniel Rodriga ao Governo veneziano ${ }^{167}$ de um adiantamento de $\mathbf{1 0 . 0 0 0}$ ducados para financiar a prospecção de novas rotas comerciais para Durazzo e Salonica}

Fonte: ASVe, Cinque Savi alla Mercanzia, Busta 139 (Risposte) fls. 169v-170r, 22.10 .1597

Ricerca Daniel Rodriga hebreo che dalla Serenità Vostra li siano dati anticipatamente o veramente ducati 3.200 della sua provisione che egli scuode all' Officio del Sale a razon de ducati 200 all'anno over ducati 10 mila all'imprestito per avviar il negozio di Salonicco e Durazzo in occasione dell'arrivo a Venezia di due navi fiamminghe cariche di sale, con molto sviamento di Ragusi e di Ancona.

${ }^{167}$ Os Sábios deram parecer favorável ao pedido, porque esta iniciativa não seria prejudicial à Escala de Split. 